Article

\title{
Study on Feng Shui (Geomantic) Suitability Evaluation of Mausoleums in Nanjing City Based on GIS
}

\author{
Jing Cui ${ }^{1} \mathbb{D}$, Yanrong Liu ${ }^{1}$, Junlin Sun ${ }^{1}\left(\mathbb{D}, \mathrm{Di} \mathrm{Hu}^{2}\right.$ and Handong He ${ }^{1, *(D)}$ \\ 1 School of Resources and Environment, Anhui Agricultural University, Hefei 230036, China; \\ cuijing@stu.ahau.edu.cn (J.C.); liuyanrong@stu.ahau.edu.cn (Y.L.); 20720671@stu.ahau.edu.cn (J.S.) \\ 2 Key Laboratory of Virtual Geographic Environment, Nanjing Normal University, Ministry of Education, \\ Nanjing 210023, China; 09374@njnu.edu.cn \\ * Correspondence: hehandong@ahau.edu.cn; Tel.: +86-152-5515-5121
}

check for updates

Citation: Cui, J.; Liu, Y.; Sun, J.; Hu, D.; He, H. Study on Feng Shui (Geomantic) Suitability Evaluation of Mausoleums in Nanjing City Based on GIS. ISPRS Int. J. Geo-Inf. 2021, 10, 752. https://doi.org/10.3390/ ijgi10110752

Academic Editor: Wolfgang Kainz

Received: 28 September 2021

Accepted: 6 November 2021

Published: 8 November 2021

Publisher's Note: MDPI stays neutral with regard to jurisdictional claims in published maps and institutional affiliations.

Copyright: (c) 2021 by the authors. Licensee MDPI, Basel, Switzerland. This article is an open access article distributed under the terms and conditions of the Creative Commons Attribution (CC BY) license (https:// creativecommons.org/licenses/by/ $4.0 /)$.
Abstract: Taking the mausoleums in the main urban area of Nanjing city as the study object, with the support of GIS technology, this paper extracts eight influencing factors (surface roughness, elevation, surface cutting depth, surface peaks, outfall, river system, slope, and aspect) corresponding to geomantic elements ("Long", "Sha", "Shui", and "Xue") in the geographical environments of mausoleums. The AHP is applied in the correlation weight method to calculate the weights of the eight influencing factors, while the information content method is applied in the grading method to calculate the numerical index of each factor. The feng shui (geomantic) suitability of the mausoleums in the main urban area of Nanjing is evaluated using the AHP-weighted information content method and by combining expert knowledge and experience with mathematical statistical techniques. According to the feng shui (geomantic) suitability evaluation results obtained for the mausoleums in the study area, the relatively low-suitability area accounts for $14.55 \%$ of the entire study area, the low-suitability area accounts for $25.40 \%$, the suitable area accounts for $29.13 \%$, the relatively high-suitability area accounts for $22.00 \%$, and the high-suitability area accounts for $8.92 \%$. Finally, through a sensitivity analysis of the model, a verification analysis applied using random mausoleums and a feng shui (geomantic) analysis of the Ming Xiaoling Mausoleum, the feng shui (geomantic) suitability evaluation results obtained for the mausoleums analyzed herein are found to be consistent with the actual distribution of the mausoleum sites. The research shows that the AHP-weighted information method based on GIS is suitable for evaluating the feng shui (geomantic) suitability of mausoleums.

Keywords: mausoleums; GIS; analytic hierarchy process; information content method; feng shui (geomantic) suitability evaluation

\section{Introduction}

Tombs are places where the remains of the dead are stored and include architectural shrines, burial vaults, church monuments, mausoleums and so on [1,2]. In China, mausoleums are traditional buildings that refer to the burial places of emperors, princes, and prominent figures. The design, site selection, and layout of mausoleums are all deeply influenced by feng shui [3-5]. Feng shui is the Chinese art or practice of positioning objects, especially graves, buildings, and furniture. Furthermore, in Chinese philosophy, feng shui is regarded as the rule governing spatial arrangements and orientations [6,7]. Therefore, studying the feng shui of mausoleums can deepen the understanding of the spatial arrangements of mausoleums and the scientific understanding of geomancy.

Analyses of the geomancy of mausoleums mainly involve the four geomantic elements of "Long", "Sha", "Shui", and "Xue" to judge spatial arrangements [8,9]. The judgments involved in geomancy must be combined with an analysis of the surrounding geographical environment [10-13]. "Long" is a mountain range and refers to the back of a mausoleum. The analysis of the mountain potential and the overall elevation of the mountains are 
important conditions to consider when placing a mausoleum. "Sha" refers to the landscape surrounding the mausoleum and is used to "gather Qi". Analyzing the mountains before and after the mausoleum is placed and visualizing the landscape of the surrounding image are other conditions to consider when placing a mausoleum. "Shui" is the outfall and river, and the search for an outfall and the observation of the flow form are conditions for the mausoleum placement. "Xue" is the specific location of the mausoleum within the surrounding environment. In a subsidence environment, the point at which the most "Qi" can be gathered is chosen [14-16]. At present, the methods used to evaluate the feng shui (geomantic) suitability of mausoleums are mainly qualitative [17-19], including the methods used by geomantic experts to obtain geomantic assessment results in the region of study through empirical judgments of the geomantic elements ("Long", "Sha", "Shui", and "Xue") in combination with the geographical environment in the field. These assessment methods rely on expert geomantic experience to a high degree [20,21].

The geomantic elements ("Long", "Sha", "Shui", and "Xue") correspond to the influencing factors (surface cutting depth, elevation, surface roughness, surface peaks, outfall, river, slope, aspect) of the geographical environment. Mausoleums, as a kind of geographical and cultural heritage site, have been studied deeply by many scholars in recent years [22-24]. The methods used to research mausoleums include not only traditional archaeological techniques but also spatial information technologies with GIS technologies as the core $[25,26]$. In terms of research content, previous studies have included not only spatial analyses of heritage sites and evolution pattern analyses of heritage sites and their surrounding environments but also some analyses of heritage risk identification and risk assessments $[27,28]$. Therefore, GIS technology can be effectively applied to evaluate the feng shui (geomantic) suitability of the geographical environment of a mausoleum based on the powerful associated spatial data acquisition, analysis and processing functions, and the complexity of the geographical environment of the studied mausoleum.

Therefore, geomantic mausoleum judgments can be regarded as suitability assessments of the geographical environments surrounding mausoleums $[29,30]$. The methods used to conduct suitability assessments of these geographical environments mainly include the correlation weight method of each influencing factor and the grading method of a single influencing factor. The correlation weight method of each influencing factor refers to the method in which the correlation of each influencing factor and the relationship between each influencing factor and the geographic environment are first determined and then the geographic environment is assessed by calculating the grading differences in the obtained spatial characteristics. These methods include the weight of evidence analysis method [31,32], logistic regression method [33,34], fuzzy comprehensive evaluation method [35,36], and analytic hierarchy process [37,38]. The weight of evidence analysis method examines the conditional independence among different influencing factors, calculates the weight coefficient of each influencing factor, and then conducts a statistical synthesis on the influencing factor layers [39,40]; in the weight evidence analysis method, it is difficult to resolve the influence of non-independence conditions on the evaluation results, and the correlations among influencing factors are ignored [41-43]. The logistic regression method has limited application conditions, as it requires a linear relationship between influencing factors and logistic probability, and the degree of fit and accuracy are not high when performing calculations; further, this method ignores the complex relationships among the geographical environment factors of the analyzed mausoleum $[44,45]$. The fuzzy comprehensive evaluation method uses the degree of membership to describe the fuzzy boundary and comprehensively evaluates the membership level of the evaluated object from multiple influencing factors [46,47]. However, this method involves complicated calculations, and the determination of the influencing factor weights is highly subjective and ignores the correlations among influencing factors [48,49]. In contrast, the analytic hierarchy process takes the research object as a system and analyzes the system in a comprehensive thinking process. This method requires less quantitative data and 
information and has become a simple and practical method used to assess the geographic environments of mausoleums [50,51].

The grading method of single influencing factor refers to the quantitative evaluation method in which the classification of each influencing factor is based on the existing geographic object; this method is performed under the assumption that no correlations exist among the influencing factors. This method reveals the degree of the geographical environment by calculating the spatial characteristic value of each influencing factor and reveals the relationship between the classification of each influencing factor and the geographical environment. These methods include the frequency ratio method $[52,53]$ and information content method [54,55]. The frequency ratio method first extracts the point density and areal density of the analyzed mausoleums, uses the frequency ratio to calculate the probability using the influencing factors, and finally superimposes the obtained data to obtain the evaluation results [56,57]. However, for mausoleum data, it is difficult to obtain accurate area information and the reliability of the calculated results is therefore low; additionally, this method ignores the complexity of the geographical environment $[58,59]$. The information content method calculates the spatial characteristics of each influencing factor based on the information content representing the given assessment level of the target mausoleum's geographic environment and uses these characteristics to measure the intimacy of each influencing factor with the mausoleum's geographic environment [60-62]. Therefore, under the assumption that no correlations exist among the various influencing factors, the information content method is more appropriate than the frequency ratio method for determining the geographic positions of mausoleums.

In the methods in which the correlation weight of each influencing factor is analyzed, the knowledge and experience of geomantic experts can be applied to the studied mausoleums to determine the correlation between each influencing factor and the relationship between each influencing factor and the geomancy of the mausoleums [63,64]. However, nonquantitative and empirical expert judgments can easily affect the evaluation results, and the objectivity of the assessment results cannot be tested. Methods in which individual influencing factors are graded can quantitatively calculate the relationship between a single influencing factor and the geomancy of mausoleums based on geographical environment data characterizing the analyzed mausoleums, thus avoiding the subjectivity of the assessment index weight value $[65,66]$. However, this method tends to ignore the correlations between influencing factors. Therefore, this paper proposes a method in which the correlation weight method of each influencing factor and the grading method of a single influencing factor are combined to assess the geomancy of mausoleums. This method not only considers the knowledge and experience of feng shui experts, but also considers the correlation among the influencing factors, so that the feng shui evaluation results of mausoleum are more scientific.

Based on GIS technology, this paper takes the main urban area of Nanjing city, Jiangsu Province as the study area and extracts eight types (surface roughness, elevation, surface cutting depth, surface peaks, outfall, river system, slope, and aspect) of geomantic mausoleum assessment factors by combining: geomancy theory; the analytical hierarchy process (AHP) is applied in the correlation weight method of each influencing factor to calculate the weights of the eight assessment factors; the information content method (I) is applied in the grading method of a single influencing factor to calculate the numerical index of each factor; a comprehensive weighting method is used to construct a geomancy assessment model of mausoleums (AHP-I); and the weight of each factor is optimally combined with a single-factor grading numerical index to assess the geomancy of mausoleums in the study area.

\section{Research Area and Research Method}

\subsection{Information of the Study Area and Utilized Data}

Nanjing city, Jiangsu Province, is located in eastern China. The Ningzhen Mountains traverse the main urban area, comprising Qinglong Mountain, Mufu Mountain, Zijin Moun- 
tain, and Qixia Mountain in the western Jiangning County. The study area is dominated by low mountains and gentle hills, with large undulations and complex and changeable topography. Dense rivers and abundant water resources are found in the territory. Nanjing is the ancient capital of the Six Dynasties and has a long history; it has long been the political, economic, and cultural center of Southern China. Emperors, princes, and prominent figures are buried in this city. The main urban area of Nanjing mainly includes eight areas: Pukou District, Qixia District, Gulou District, Jianye District, Xuanwu District, Qinhuai District, Yuhuatai District, and Jiangning District.

According to the cultural relic protection unit information published by China's State Administration of Cultural Heritage, this paper selected the mausoleums in national, provincial, and municipal cultural relic protection units within the study area as research objects (42 mausoleums in total). These mausoleums were divided into categories such as emperor mausoleums, dukes under an emperor mausoleum, and general ministers mausoleums, as shown in Table 1 and Figure 1. The spatial information and attributes of these mausoleums were collected and entered into a database. In the mausoleum database, each mausoleum is represented by a data point, and its corresponding attribute information includes its name, longitude, latitude, dynasty, and the corresponding spatial attribute values of 8 influencing factors, as shown in Figure 2. The spatial distribution of mausoleums in the study area is shown in Figure 3.

Table 1. Research data introduction.

\begin{tabular}{|c|c|c|}
\hline Categories & Number & Example \\
\hline Emperor mausoleums & 4 & $\begin{array}{c}\text { Ming Xiaoling Mausoleum, two mausoleums of the } \\
\text { Southern Tang Dynasty }\end{array}$ \\
\hline Ancient buildings & 2 & Li Wenzhong tomb, Sun Wu tomb \\
\hline Ancient mausoleums & 27 & Wu Liang tomb, Deng Yu tomb \\
\hline Stone carvings and grottoes & 7 & $\begin{array}{l}\text { Badou Mountain ancient tomb group, Muling family } \\
\text { mausoleums group }\end{array}$ \\
\hline Other categories & 2 & $\begin{array}{l}\text { Xianheguan cemetery of the Six Dynasties, } \\
\text { mausoleums of Princess Fuqing }\end{array}$ \\
\hline \multirow{4}{*}{ Some data sources: } & & $\begin{array}{l}\text { http:/ / wlj.nanjing.gov.cn/zwgk/wwbhml/201912 } \\
\text { /t20191206_1731771.html (accessed on 12 June 2019) }\end{array}$ \\
\hline & & $\begin{array}{l}\text { http:/ /wlj.nanjing.gov.cn/zwgk/wwbhml/201912 } \\
\text { /t20191206_1731763.html (accessed on 12 June 2019) }\end{array}$ \\
\hline & & $\begin{array}{l}\text { http://wlj.nanjing.gov.cn/zwgk/wwbhml/201912 } \\
\text { /t20191206_1731726.html (accessed on } 12 \text { June 2019) }\end{array}$ \\
\hline & & $\begin{array}{l}\text { http:/ / wlj.nanjing.gov.cn/zwgk/wwbhml/201912 } \\
\text { /t20191206_1731768.html (accessed on 12 June 2019) }\end{array}$ \\
\hline
\end{tabular}




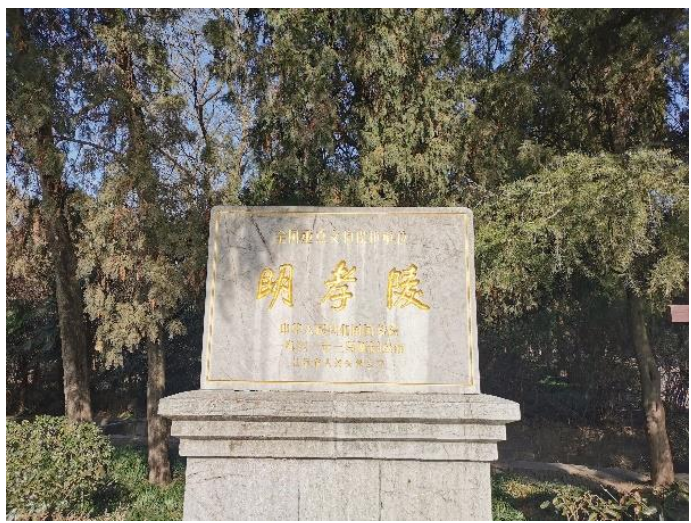

(a)

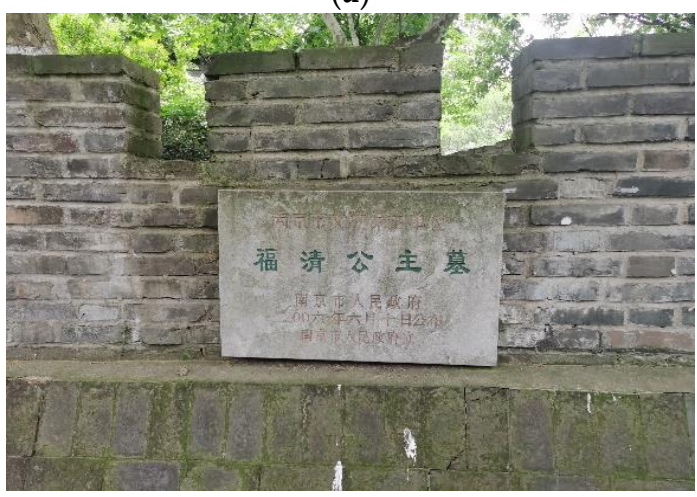

(c)

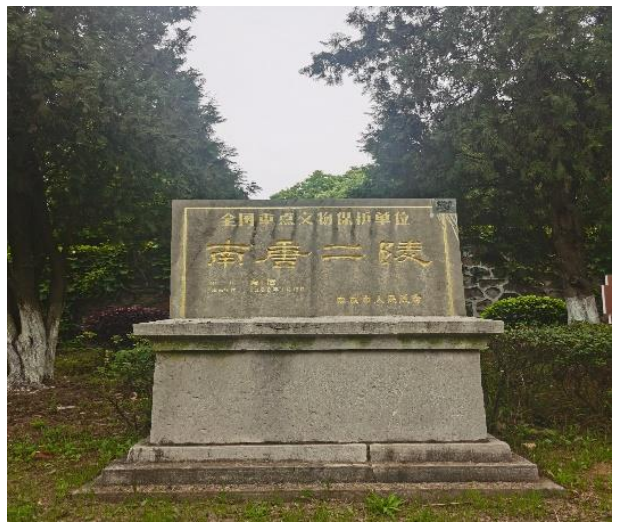

(b)



(d)

Figure 1. Examples of mausoleums: (a) the Ming Xiaoling Mausoleum, (b) the two mausoleums of the Southern Tang Dynasty, (c) the tomb of Princess Fuqing, (d) Xu Da tomb.



Figure 2. Attribute table of mausoleum data. 


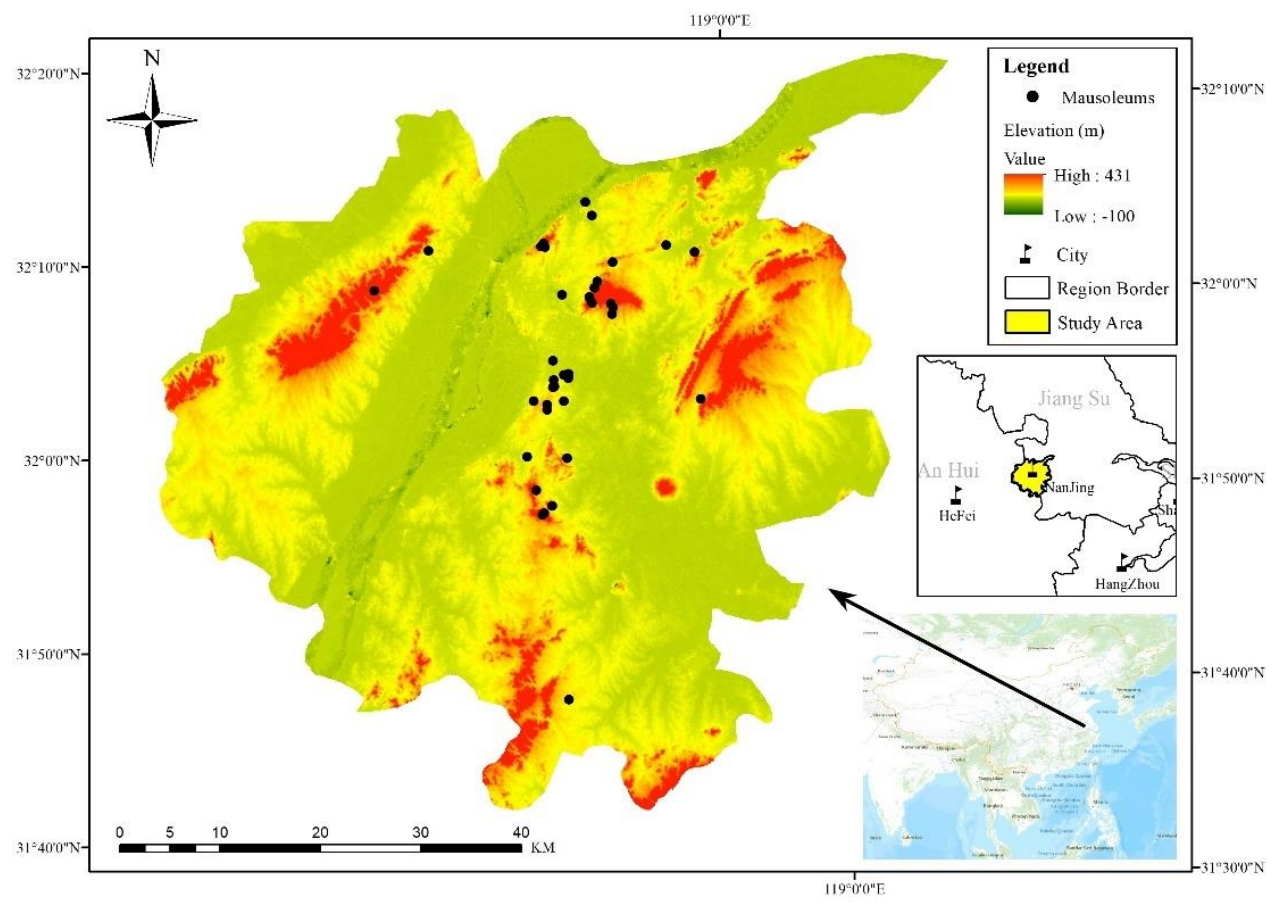

Figure 3. Spatial distribution of mausoleum sites in the study area.

\subsection{Selection of Assessment Factors and Data Sources}

Geomantic elements ("Long", "Sha", "Shui", and "Xue") correspond to influencing factors (surface roughness, elevation, surface cutting depth, surface peaks, outfall, river system, slope, and aspect) in the geographical environment, and the judgment of mausoleum geomancy can be regarded as an assessment of the suitability of the mausoleum environment.

"Long", in feng shui theory (hypothesis), refers to mountains and the trends of mountains, and mainly corresponds to feng shui suitability judgments through the observation of the overall situation of a large mountain range in the geographical environment and the specific situation of the surrounding mountains. In geography, the surface roughness is an index reflecting the impact of the land surface on sand activities and its weakening impact on the wind speed, as well as the ability of the land surface to resist wind erosion. According to the surface roughness, the wind resistance of the geographical environment can be judged. Strong wind resistance in a given area can ensure that the "Qi" of the local environment is not dispersed and that the feng shui suitability is high. On the other hand, the elevation of a given area can express the relative height of the local mountains. Therefore, the surface roughness and elevation metrics can be used as the basic criterion for analyzing "Long" in Feng Shui.

"Sha", according to feng shui theory (hypothesis), refers to the low and gentle hills around a mausoleum. Its function is to let the "Long" surrounding the overall environment cover the strong wind and protect the "Qi" of the small environment to achieve wind accumulation. In geography, the surface cutting depth refers to the erosion degree of the land surface by natural factors (such as water, wind, and sand). The degree of surface cutting can represent the hill or shallow basin density. The relief of hills can be judged using the hill density. On the other hand, the peak point of a local area can be extracted to more intuitively judge the locations of hills. Through observations of the locations of hills, it can be determined whether the hills around and in front of a mausoleum are surrounded by similar topography in the geographical environment. Therefore, the analyses of the surface cutting depth and peak point can be used as the basic criterion of "Sha" in feng shui applications.

In feng shui theory (hypothesis), "Shui" mainly refers to the outfall and shape of water in a local environment. The outfall is the outlet of flowing water in a basin and the lowest point of the whole basin. The feng shui suitability can be judged according to the distance 
from the outfall. The basic requirement for the water shape in areas with high feng shui suitability is "buckling embracing". The feng shui suitability can thus be judged according to the distance from the dendritic river system. Therefore, the use of the two geographical environmental factors of the outfall and river system can serve as the basic criterion of "Shui" in feng shui applications.

"Xue", in feng shui theory (hypothesis), refers to the determination of the specific location of a mausoleum. "Xue" refers to finding the most "Qi-gathering" position in the subsidence environment to build a mausoleum. The premise of "gathering Qi" is that "Qi" should be transported through the rolling "Long". Therefore, "Xue" and "Long" are closely related. The influence of mountain slopes and aspect on feng shui suitability should be considered. Aspect is the direction facing the slope, and its numerical value reflects the projection direction of the sun on the surface. The aspect can be divided into shaded slopes and sunny slopes, and different solar directions have different influences on the location of mausoleums. Therefore, the consideration of known mausoleum points, sunny slopes, and shaded slopes can be used as the basic criterion of "Xue" in feng shui applications.

In summary, these eight influencing factors (surface roughness, elevation, surface cutting depth, surface peaks, outfall, river system, slope, and aspect) can be used as geomantic suitability evaluation factors for mausoleums. The sources of the influencing factor data are shown in Table 2. The corresponding table of geomantic elements and influencing factors is shown in Table 3.

Table 2. Research data introduction.

\begin{tabular}{ccc}
\hline Influencing factors & Data source & Description \\
\hline Surface roughness & Extracted from a digital elevation model & (DEM) \\
Elevation & https:/ / www.usgs.gov / (accessed on 5 & Different spatial values \\
Surface cutting depth & November 2021) & $90 \mathrm{~m}$ DEM \\
Surface peaks & Extracted from a DEM & Different spatial values \\
Outfall & Extracted from a DEM & Distance from the top of a mountain \\
River system & Extracted from a DEM & Inlet and outlet of flowing water \\
Slope & (accessed on 5 November 2021) & Water network system in the basin \\
Aspect & Extracted from a DEM & The direction from high to low \\
& Extracted from a DEM & Sunny slopes and shaded slopes \\
\hline
\end{tabular}

Table 3. Corresponding table of geomantic elements and influencing factors.

\begin{tabular}{|c|c|c|c|c|c|}
\hline $\begin{array}{l}\text { Geomantic } \\
\text { Elements }\end{array}$ & $\begin{array}{l}\text { Feng Shui } \\
\text { Definition }\end{array}$ & $\begin{array}{l}\text { Influencing } \\
\text { Factors }\end{array}$ & $\begin{array}{l}\text { Geographical Definition } \\
\text { References }[67-70]\end{array}$ & Graphs & $\begin{array}{c}\text { Graphs } \\
\text { References } \\
{[8,9,71]}\end{array}$ \\
\hline \multirow[t]{2}{*}{ “Long” } & \multirow{2}{*}{$\begin{array}{l}\text { Indicates the } \\
\text { trends of } \\
\text { mountains and } \\
\text { mountain ranges. }\end{array}$} & $\begin{array}{l}\text { Surface } \\
\text { roughness }\end{array}$ & $\begin{array}{l}\text { Indicates the weakening } \\
\text { effect of the land surface on } \\
\text { the wind speed and the } \\
\text { wind-sand interactive } \\
\text { activity. Can be used to } \\
\text { describe the "Long" } \\
\text { component in the feng shui } \\
\text { of mausoleums }\end{array}$ & & \\
\hline & & Elevation & $\begin{array}{l}\text { Indicates the relative height } \\
\text { of a mountain. Can be used } \\
\text { to describe the "Long" } \\
\text { component in the feng shui } \\
\text { of mausoleums }\end{array}$ & & \\
\hline
\end{tabular}


Table 3. Cont

\begin{tabular}{|c|c|c|c|c|c|}
\hline $\begin{array}{l}\text { Geomantic } \\
\text { Elements }\end{array}$ & $\begin{array}{l}\text { Feng Shui } \\
\text { Definition }\end{array}$ & $\begin{array}{l}\text { Influencing } \\
\text { Factors }\end{array}$ & $\begin{array}{l}\text { Geographical Definition } \\
\text { References [67-70] }\end{array}$ & Graphs & $\begin{array}{c}\text { Graphs } \\
\text { References } \\
{[8,9,71]}\end{array}$ \\
\hline \multirow{2}{*}{ "Sha" } & \multirow{2}{*}{$\begin{array}{l}\text { Indicates low } \\
\text { hills and their } \\
\text { forms around } \\
\text { and in front of a } \\
\text { mausoleum }\end{array}$} & $\begin{array}{l}\text { Surface cutting } \\
\text { depth }\end{array}$ & $\begin{array}{l}\text { Indicates the density of hills. } \\
\text { Can be used to describe the } \\
\text { "Sha" component in the feng } \\
\text { shui of mausoleums }\end{array}$ & & \\
\hline & & Surface peaks & $\begin{array}{l}\text { Indicates an area higher } \\
\text { than the surrounding points } \\
\text { within the analysis scope of } \\
\text { a specific field. Can be used } \\
\text { to describe the "Sha" } \\
\text { component in the feng shui } \\
\text { of mausoleums }\end{array}$ & & \\
\hline \multirow{2}{*}{ "Shui" } & \multirow{2}{*}{$\begin{array}{l}\text { Indicates outfall } \\
\text { and water shape. }\end{array}$} & Outfall & $\begin{array}{l}\text { Indicates the outlet of } \\
\text { flowing water in the basin, } \\
\text { corresponding to the lowest } \\
\text { point of the whole basin }\end{array}$ & & \\
\hline & & River system & $\begin{array}{l}\text { Indicates the water network } \\
\text { system composed of all } \\
\text { rivers, lakes, and other } \\
\text { water bodies in the basin }\end{array}$ & & \\
\hline \multirow[t]{2}{*}{ "Xue" } & \multirow{2}{*}{$\begin{array}{l}\text { Indicates the } \\
\text { specific location } \\
\text { of the } \\
\text { mausoleum }\end{array}$} & Slope & $\begin{array}{l}\text { Indicates the degree of } \\
\text { steepness and gentleness of } \\
\text { surface units. For } \\
\text { mausoleum points, a buffer } \\
\text { zone is established by } \\
\text { taking the slope value as the } \\
\text { distance interval; this } \\
\text { interval can be used to } \\
\text { describe the "Xue" } \\
\text { component in the feng shui } \\
\text { of mausoleums }\end{array}$ & & \\
\hline & & Aspect & $\begin{array}{l}\text { Indicates the direction of } \\
\text { mountains from high to low. } \\
\text { Extracting the slope } \\
\text { direction of mausoleums } \\
\text { can distinguish between } \\
\text { sunny and shaded slopes; } \\
\text { this information can be used } \\
\text { to describe the "Xue" } \\
\text { component in the feng shui } \\
\text { of mausoleums }\end{array}$ & & \\
\hline
\end{tabular}

\subsection{AHP-Weighted Information Content Method}

In this paper, a weighted AHP information method is proposed to evaluate the feng shui suitability of mausoleums. This weighted method comprehensively evaluates the influencing factors of various geographical environments as well as the contribution degree within the quantified classification range from the overall and partial dimensions. Its essence is to quantify the cognitive evaluation of the geographical environment in terms of feng shui through the use of GIS mathematical statistics. 
(1) First, the weight value of the target geographical environment influencing factor is calculated by the AHP method to characterize the importance of the influencing factor to the feng shui suitability of the analyzed mausoleum.

The eight influencing factors are arranged, their relative importance is compared, and a judgment matrix is constructed. The matrix is shown in (Equation (1)).

$$
\mathrm{x}=\left[\begin{array}{cccc}
\mathrm{x}_{11} & \mathrm{x}_{12} & \ldots & \mathrm{x}_{1 \mathrm{p}} \\
\mathrm{x}_{21} & \mathrm{x}_{22} & \ldots & \mathrm{x}_{2 \mathrm{p}} \\
\ldots & \ldots & \ldots & \ldots \\
\mathrm{x}_{\mathrm{q} 1} & \mathrm{x}_{\mathrm{q} 2} & \ldots & \mathrm{x}_{\mathrm{qp}}
\end{array}\right]
$$

The weight calculation formula used to determine the weights of various factors influencing the mausoleum geographical environment is shown as follows (Equation (2)):

$$
\mathrm{W}_{\mathrm{i}}=\frac{1}{\mathrm{q}} \sum_{\mathrm{q}=1}^{\mathrm{q}} \frac{\mathrm{x}_{\mathrm{pq}}}{\sum_{\mathrm{p}=1}^{\mathrm{q}} \mathrm{x}_{\mathrm{pq}}}
$$

(2) Second, the information value of each geographical environment influencing factor in its different classification range is calculated by the information content method to represent the contribution degree of an influencing factor in various classifications. The calculation formula of the information method is shown as follows (Equation (3)):

$$
\mathrm{I}_{\mathrm{X}_{\mathrm{i}}}=\ln \frac{\mathrm{T}_{\mathrm{i}} / \mathrm{T}}{\mathrm{S}_{\mathrm{i}} / \mathrm{S}}
$$

In Equation (3), $T_{i}$ is the influencing factor $\left(x_{i}\right)$ corresponding to the number of mausoleums distributed in each level unit; $T$ is the total number of tombs in the study area; $\mathrm{S}_{\mathrm{i}}$ is the influencing factor $\left(\mathrm{x}_{\mathrm{i}}\right)$ corresponding to the total number of grid cells; and $\mathrm{S}$ is the total number of grid cells in the study area.

(3) Finally, the comprehensive weighted method is used to calculate the compound operation to obtain the feng shui evaluation results of the analyzed mausoleum in the study area, as shown in the following equation (Equation (4)).

$$
\mathrm{R}=\sum \mathrm{W}_{\mathrm{i}} \mathrm{I}_{\mathrm{ij}}=\mathrm{W}_{1} \mathrm{I}_{1 \mathrm{j}}+\mathrm{W}_{2} \mathrm{I}_{2 \mathrm{j}}+\mathrm{W}_{3} \mathrm{I}_{3 \mathrm{j}}+\mathrm{W}_{4} \mathrm{I}_{4 \mathrm{j}}+\mathrm{W}_{5} \mathrm{I}_{5 \mathrm{j}}+\mathrm{W}_{6} \mathrm{I}_{6 \mathrm{j}}+\mathrm{W}_{7} \mathrm{I}_{7 \mathrm{j}}+\mathrm{W}_{8} \mathrm{I}_{8 \mathrm{j}}
$$

In Equation (4), $\mathrm{W}_{1}-\mathrm{W}_{8}$ correspond to the importance degrees of various influencing factors, as calculated by the AHP method, considering the location of mausoleums, and $\mathrm{I}_{1}-\mathrm{I}_{8}$ are the contribution values of various geographical environmental influencing factors, as calculated by the information method for different classification ranges.

According to the distribution characteristics of the mausoleums in the study area, the geographical environmental influencing factors (surface roughness, elevation, surface cutting depth, surface peaks, outfall, river system, slope, and aspect) of mausoleum geomancy are graded as follows:

(a) Surface roughness: according to the roughness index, the surface roughness is divided into four levels: 1-1.000064, 1.000064-1.0016, 1.0016-1.04, >1.04.

(b) Elevation: according to the natural breakpoint method, the elevation is divided into four levels: 0-50 m, 50-100 m, and >100 m.

(c) Surface cutting depth: according to the natural breakpoint method, the surface cutting depth is divided into four levels: 0-7.3 m, 7.3-19.8 m, 19.8-39.5 m, and $>39.5 \mathrm{~m}$.

(d) Surface peaks: a multiring buffer zone is established for the surface peaks, which are divided into the following categories: $>8 \mathrm{~km}, 6-8 \mathrm{~km}, 4-6 \mathrm{~km}, 2-4 \mathrm{~km}$, and $0-2 \mathrm{~km}$.

(e) Outfall: a multiring buffer zone is established for the outfall, which is divided into the following categories: $>6 \mathrm{~km}, 3-6 \mathrm{~km}$, and $0-3 \mathrm{~km}$. 
(f) River system: a multiring buffer zone is established for the river systems, which are divided into: $>3 \mathrm{~km}, 2-3 \mathrm{~km}, 1-2 \mathrm{~km}, 0-1 \mathrm{~km}$.

(g) Slope: for the mausoleum points, multiple buffer zones are established with the slope as the distance: $<10 \mathrm{~km}, 10-15 \mathrm{~km}, 15-20 \mathrm{~km}$, and $>20 \mathrm{~km}$.

(h) Aspect: the slope direction of each mausoleum is extracted; then, the slope direction is divided into one of the following categories according to the slope: flat slope, shaded slopes, semi-shaded slopes, semi-sunny slopes, and sunny slopes.

Figure 4 shows the classification results of the assessment factors of the feng shui of mausoleums.

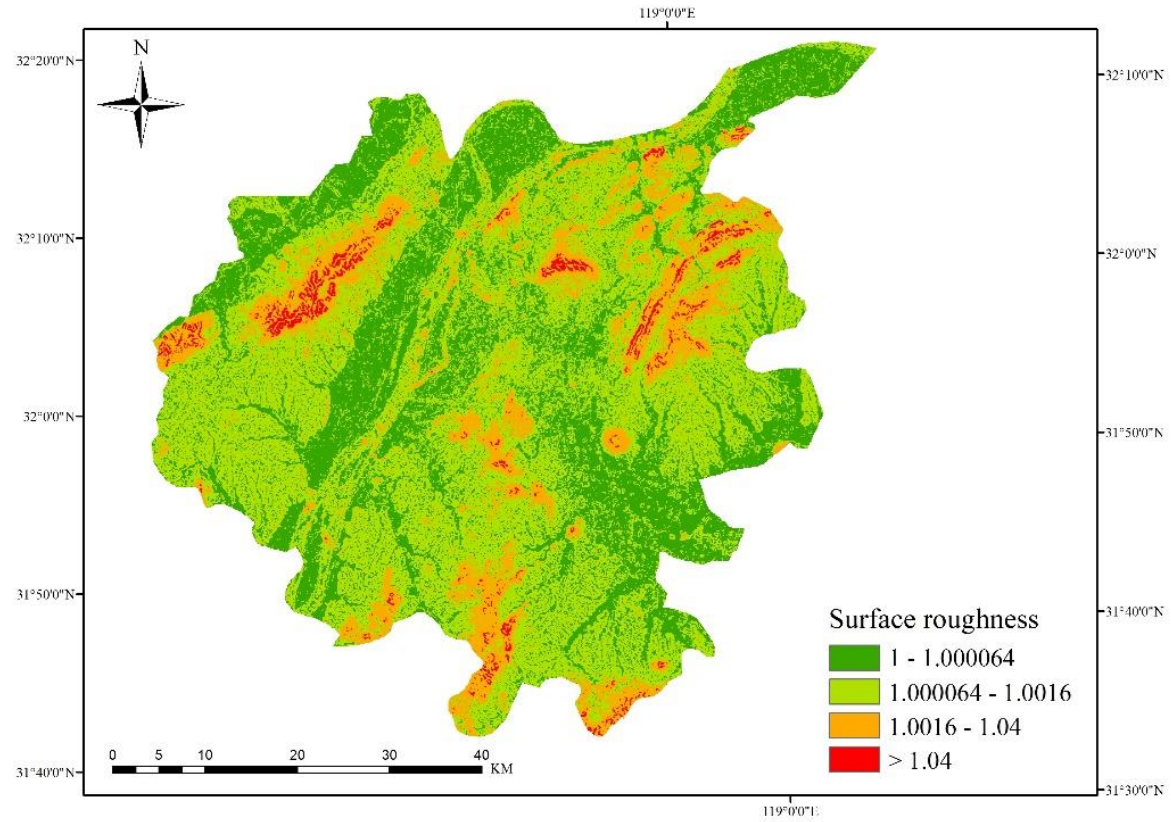

(a)

Figure 4. Cont. 


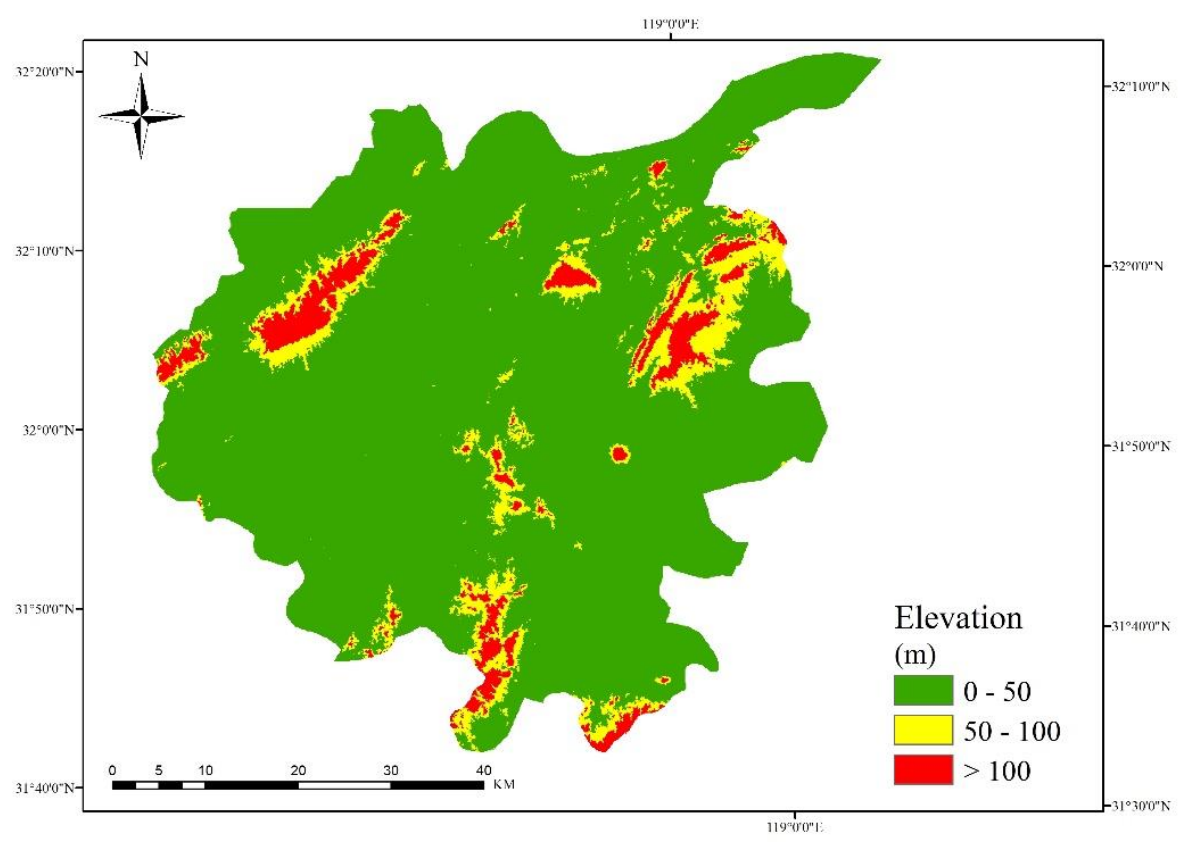

(b)

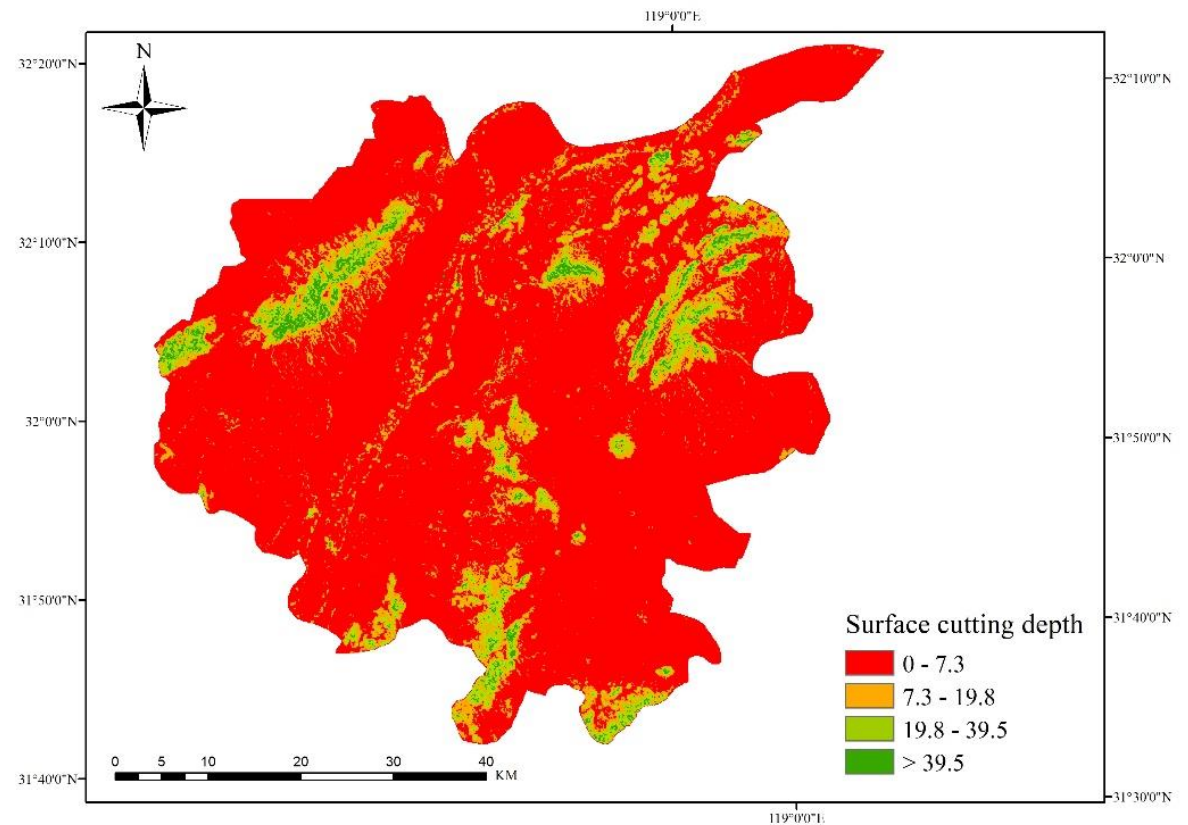

(c)

Figure 4. Cont. 


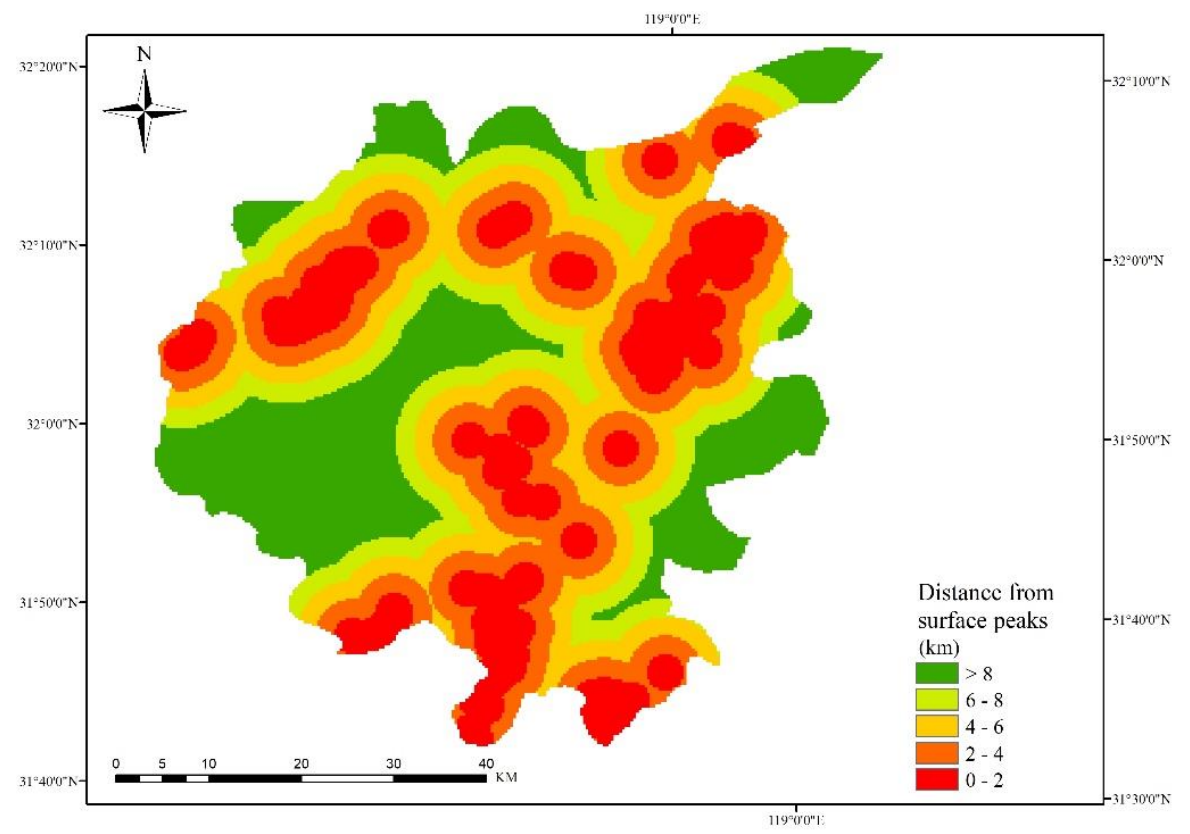

(d)



(e)

Figure 4. Cont. 


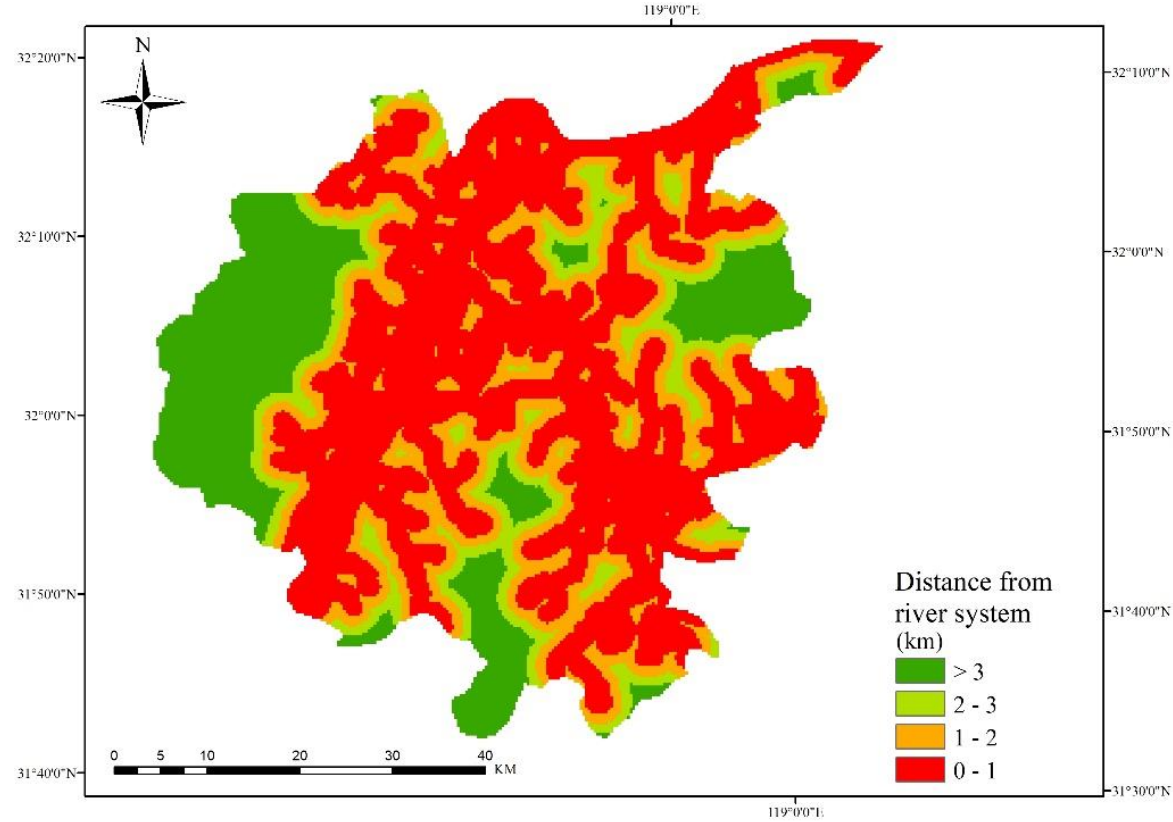

(f)



(g)

Figure 4. Cont. 


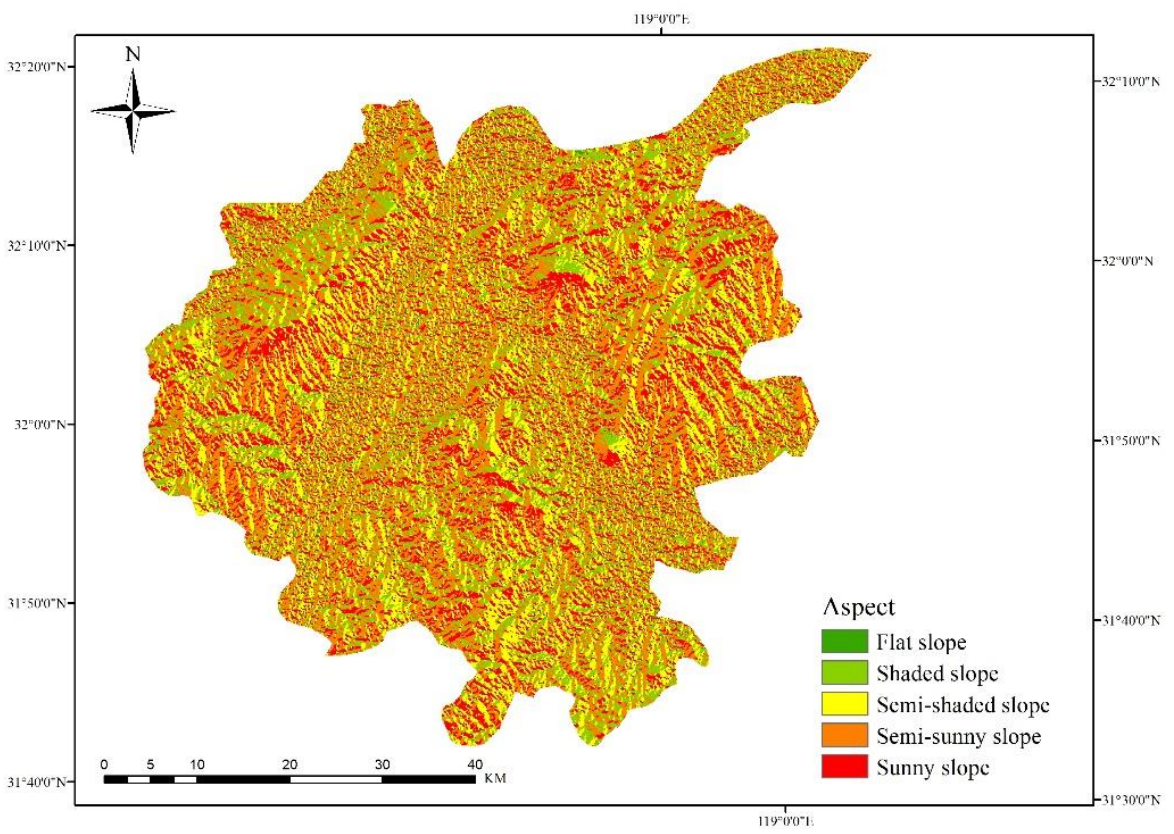

(h)

Figure 4. Classification of the information contents of the analyzed influencing factors: (a) surface roughness, (b) elevation, (c) surface cutting depth, (d) surface peaks, (e) outfall, (f) river system, (g) slope, and (h) aspect.

\section{Experiment}

\subsection{Calculation of the AHP Method}

After establishing the assessment index system using the extracted eight factors influencing mausoleum geomancy, a judgment matrix of the mausoleum-related geomantic assessment factors in the study area was constructed according to the actual situation of study area combined with the experience of experts. This matrix is shown in Table 4. After normalizing the judgment matrix, the weight of each assessment factor was obtained, as shown in Table 5.

Table 4. AHP judgment matrix containing influencing factors of mausoleum geomancy.

\begin{tabular}{ccccccccc}
\hline & F1 & F2 & F3 & F4 & F5 & F6 & F7 & F8 \\
\hline F1 & 1 & 3 & 1 & 6 & 1 & 4 & 3 & 4 \\
F2 & $1 / 3$ & 1 & $1 / 4$ & $1 / 5$ & $1 / 2$ & 2 & $1 / 2$ & 2 \\
F3 & 1 & 4 & 1 & 6 & 1 & 5 & 3 & 4 \\
F4 & $1 / 6$ & 5 & $1 / 6$ & 1 & $1 / 4$ & $1 / 2$ & $1 / 3$ & $1 / 2$ \\
F5 & 1 & 2 & 1 & 4 & 1 & 3 & 2 & 3 \\
F6 & $1 / 4$ & $1 / 2$ & $1 / 5$ & 2 & $1 / 3$ & 1 & $1 / 2$ & 1 \\
F7 & $1 / 3$ & 2 & $1 / 3$ & 3 & $1 / 2$ & 2 & 1 & 1 \\
F8 & $1 / 4$ & $1 / 2$ & $1 / 4$ & 2 & $1 / 3$ & 1 & 1 & 1
\end{tabular}

F1 = surface roughness; F2 = elevation; F3 = surface cutting depth; F4 = surface peaks; F5 = outfall; F6 = river system; F7 = slope; F8 = aspect.

Table 5. The normalized weight of each influencing factor.

\begin{tabular}{ccccccccc}
\hline Factors & F1 & F2 & F3 & F4 & F5 & F6 & F7 & F8 \\
\hline Weight & $22.63 \%$ & $7.19 \%$ & $23.99 \%$ & $6.69 \%$ & $18.36 \%$ & $5.53 \%$ & $9.38 \%$ & $6.23 \%$ \\
\hline
\end{tabular}

F1 = surface roughness; F2 = elevation; F3 = surface cutting depth; F4 = surface peaks; F5 = outfall; F6 = river system; F7 = slope; F8 = aspect. 
To prevent logical contradictions in the scoring matrix, it was necessary to test the consistency of the matrix and the coordination between the assessment factor weights. The test calculation is shown in Table 6 , and CR $=0.096<1$, indicating that the consistency test passed.

Table 6. Test calculation value.

\begin{tabular}{cccc}
\hline Inspection Index & CI & RI & CR \\
\hline Value & 0.136 & 1.410 & 0.096 \\
\hline
\end{tabular}

\subsection{Calculation of the Information Content Method}

According to the classification of the eight influencing factors of mausoleum geomancy combined with the current discovery of mausoleum distribution points, the information content method was used to calculate the amount of information contained within each influencing factor classification result. The results are shown in Table 7.

Table 7. Calculation of the information contents of the influence factors.

\begin{tabular}{|c|c|c|c|c|c|c|}
\hline Factor & Level & $\mathrm{T}_{\mathrm{i}}$ & $\mathrm{T}_{\mathrm{i}} / \mathrm{T}$ & $\mathrm{S}_{\mathrm{i}} / \mathrm{S}$ & I & Rank \\
\hline \multirow{4}{*}{$\begin{array}{l}\text { Surface } \\
\text { roughness }\end{array}$} & $1-1.000064$ & 3 & 0.6429 & 0.8468 & -0.275 & 20 \\
\hline & $\begin{array}{l}1.000064- \\
1.0016\end{array}$ & 13 & 0.1429 & 0.0805 & 0.5734 & 9 \\
\hline & $1.0016-1.04$ & 23 & 0.2143 & 0.0486 & 1.4833 & 2 \\
\hline & $>1.04$ & 3 & 0.8333 & 0.9451 & -0.1259 & 18 \\
\hline \multirow{3}{*}{ Elevation } & $0-50 \mathrm{~m}$ & 27 & 0.6429 & 0.8709 & -0.3036 & 21 \\
\hline & $50-100 \mathrm{~m}$ & 6 & 0.1429 & 0.0805 & 0.5734 & 12 \\
\hline & $>100 \mathrm{~m}$ & 9 & 0.2143 & 0.0486 & 1.4833 & 7 \\
\hline \multirow{4}{*}{$\begin{array}{c}\text { Surface } \\
\text { cutting depth }\end{array}$} & $0-7.3 \mathrm{~m}$ & 18 & 0.4286 & 0.8244 & -0.6542 & 22 \\
\hline & $7.3-19.8 \mathrm{~m}$ & 14 & 0.3333 & 0.1113 & 1.0971 & 10 \\
\hline & $19.8-39.5 \mathrm{~m}$ & 7 & 0.1667 & 0.0475 & 1.2543 & 9 \\
\hline & $>39.5 \mathrm{~m}$ & 3 & 0.0714 & 0.0168 & 1.4494 & 8 \\
\hline \multirow{5}{*}{ Surface peaks } & $>8 \mathrm{~km}$ & 7 & 0.1667 & 0.2514 & -10.9359 & 29 \\
\hline & $6-8 \mathrm{~km}$ & 7 & 0.1667 & 0.1465 & -10.3960 & 28 \\
\hline & $4-6 \mathrm{~km}$ & 5 & 0.1190 & 0.1979 & -11.0329 & 30 \\
\hline & $2-4 \mathrm{~km}$ & 3 & 0.0714 & 0.2196 & -11.6480 & 31 \\
\hline & $0-2 \mathrm{~km}$ & 20 & 0.4762 & 0.1845 & -9.5766 & 27 \\
\hline \multirow{3}{*}{ Outfall } & $>6 \mathrm{~km}$ & 8 & $0.1905^{\prime}$ & 0.4904 & -0.9456 & 23 \\
\hline & $3-6 \mathrm{~km}$ & 19 & 0.4524 & 0.3175 & 0.3540 & 15 \\
\hline & $0-3 \mathrm{~km}$ & 15 & 0.3571 & 0.1921 & 0.6201 & 11 \\
\hline \multirow{4}{*}{ River system } & $>3 \mathrm{~km}$ & 3 & 0.0714 & 0.2035 & -1.0469 & 24 \\
\hline & $2-3 \mathrm{~km}$ & 7 & 0.1667 & 0.0946 & 0.5659 & 13 \\
\hline & $1-2 \mathrm{~km}$ & 13 & 0.3095 & 0.1964 & 0.4551 & 14 \\
\hline & $0-1 \mathrm{~km}$ & 19 & 0.4524 & 0.5055 & -0.1110 & 18 \\
\hline \multirow{4}{*}{ Slop } & $<10 \mathrm{~km}$ & 3 & 0.0714 & 0.9490 & -2.5867 & 25 \\
\hline & $10-15 \mathrm{~km}$ & 13 & 0.3095 & 0.0213 & 2.6762 & 5 \\
\hline & $15-20 \mathrm{~km}$ & 4 & 0.0952 & 0.0152 & 1.8372 & 6 \\
\hline & $>20 \mathrm{~km}$ & 22 & 0.5238 & 0.0145 & 3.5868 & 3 \\
\hline \multirow{5}{*}{ Aspect } & flat slope & 1 & 0.0238 & 0.0216 & 0.0968 & 17 \\
\hline & shaded slope & 7 & 0.1667 & 0.2032 & -0.1981 & 19 \\
\hline & $\begin{array}{l}\text { semi-shaded } \\
\text { slope }\end{array}$ & 16 & 0.3810 & 0.2751 & 0.3255 & 16 \\
\hline & $\begin{array}{l}\text { semi-sunny } \\
\text { slope }\end{array}$ & 10 & 0.2381 & 0.2575 & -0.0783 & 18 \\
\hline & sunny slope & 8 & 0.1905 & 0.2426 & -0.2420 & 20 \\
\hline
\end{tabular}


In Table $7, \mathrm{~T}_{\mathrm{i}}$ represents the number of mausoleums within a given hierarchical influencing factor in the study area, $\mathrm{T}_{\mathrm{i}} / \mathrm{T}$ represents the number of mausoleums within a given hierarchical influence factor in the study area as a proportion of the total number of mausoleums, and $S_{i} / S$ represents the proportion of the number of grading influencing factor units in the study area to the total number of units. Rank represents the order of the amount of information corresponding to each influencing factor from small to large.

\subsection{Calculation of the Comprehensive Weighting Method (AHP-I)}

The comprehensive weighting method (AHP-I) refers to a combination of the weights of the eight analyzed influencing factors, as calculated using the AHP method, with the information contents that were graded by each influencing factor, as calculated using the information content method (I). In this paper, the weighting calculations were combined with the relevant calculations shown in Tables 4 and 6 . The calculation equation is shown as follows (Equation (5)). The analysis results are shown in Figure 5.

$$
\begin{gathered}
\mathrm{R}=\sum \mathrm{W}_{\mathrm{i}} \times \mathrm{I}_{\mathrm{ij}}=0.2263 \times \mathrm{I}_{1 \mathrm{j}}+0.0719 \times \mathrm{I}_{2 \mathrm{j}}+0.2399 \times \mathrm{I}_{3 \mathrm{j}}+0.0669 \times \mathrm{I}_{4 \mathrm{j}} \\
+0.1836 \times \mathrm{I}_{5 \mathrm{j}}+0.0553 \times \mathrm{I}_{6 \mathrm{j}}+0.0938 \times \mathrm{I}_{7 \mathrm{j}}+0.0623 \times \mathrm{I}_{8 \mathrm{j}}
\end{gathered}
$$

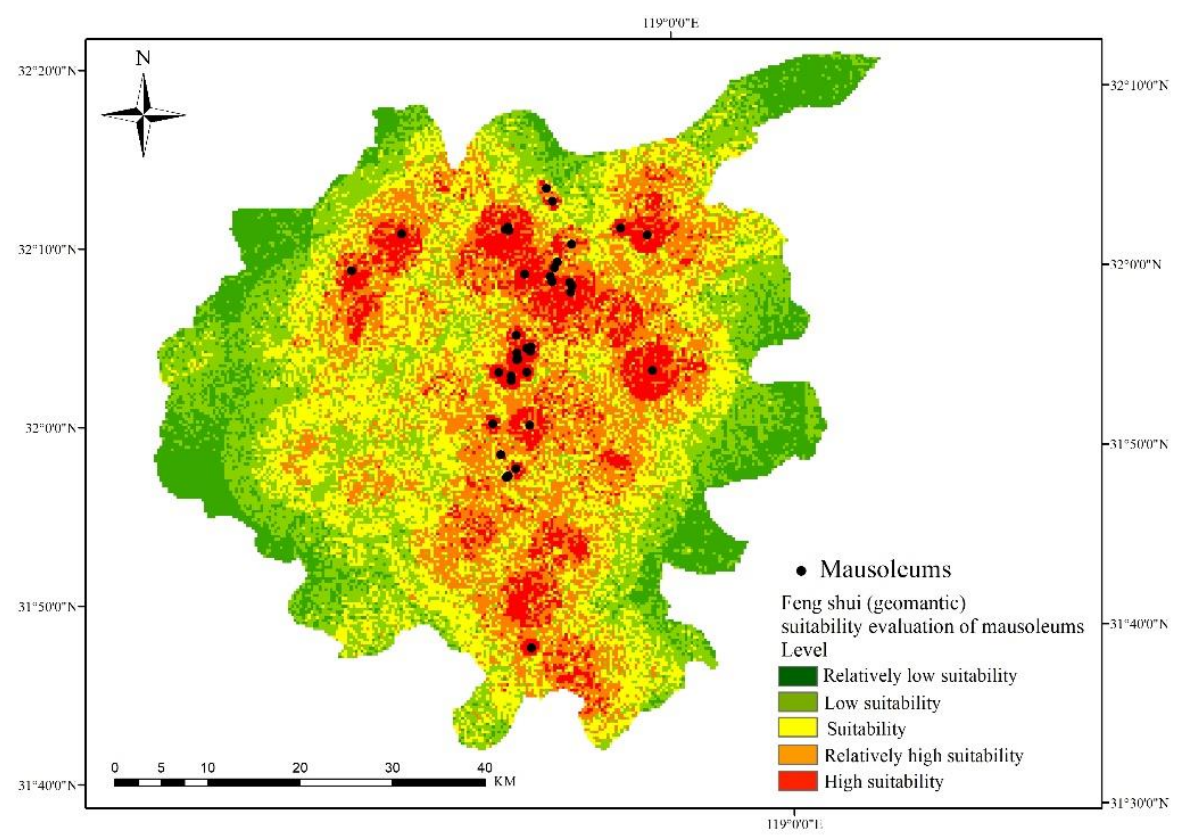

Figure 5. Feng shui suitability evaluation results of mausoleums using AHP-I.

According to the geomantic mausoleums assessment results obtained with the comprehensive weighting method (AHP-I), the level of mausoleum geomancy in the main urban area of Nanjing was divided into five levels (relatively low suitability, low suitability, suitability, relatively high suitability, and high suitability) using the natural breakpoint method, which is commonly used in mathematical statistics. By combining the results with GIS-derived spatial statistics, the area of each level was counted. The results showed that the relatively low-suitability area accounted for $14.55 \%$ of the overall study area, the low-suitability area accounted for $25.40 \%$, the suitable area accounted for $29.13 \%$, the relatively high-suitability area accounted for $22.00 \%$, and the high-suitability area accounted for $8.92 \%$. These results are shown in Figure 6. 




Figure 6. The area proportion of each suitability level to the total study area.

Following Table 4 and in conjunction with the list of weighted information contents derived for mausoleums in the main urban area of Nanjing (Table 7), the characteristics of the relatively high-suitability and high-suitability regions within Nanjing city were determined using the following steps:

(a) The surface roughness reflects the weakening effect of the surface on the wind speed and the influence of the land surface on wind-sand activity. Surface roughness is a corresponding influencing factor of "Long". The surface roughness ranges from 1.0016 to 1.22 in the feng-shui-suitable mausoleum area.

(b) The elevation reflects the terrain in a small region. Elevation is a corresponding influencing factor of "Long". Clearly, the elevation ranges from 1 to $100 \mathrm{~m}$ in the feng-shui-suitable mausoleum area.

(c) The surface cutting depth reflects the hill density and is a corresponding influencing factor of "Sha". The surface cutting depth ranges from 19.8 to 39.5 in the feng-shuisuitable mausoleum area.

(d) Surface peaks reflect the area higher than the surrounding points within the analysis scope of a specific field. Surface peaks are a corresponding influencing factor of "Sha". The surface peaks range from 0 to $2 \mathrm{~km}$ in the feng-shui-suitable mausoleum area.

(e) The outfall reflects the outlet of flowing water in a basin and corresponds to the lowest point in the entire basin. The outfall is a corresponding influencing factor of "Shui". The outfall ranges from 3 to $6 \mathrm{~km}$ in the feng-shui-suitable mausoleum area.

(f) The river system reflects the water network system composed of all rivers, lakes and other water bodies in the analyzed basin. The river system is a corresponding influencing factor of "Shui". The river system ranges from 0 to $2 \mathrm{~km}$ in the feng-shuisuitable mausoleum area.

(g) The slope reflects the steepness and gentleness degrees of the analyzed surface units and is a corresponding influencing factor of "Xue". The slope ranges from 10 to 15 $\mathrm{km}$ in the feng-shui-suitable mausoleum area.

(h) The aspect reflects the direction faced by mountains from high to low. The extracted slope directions of mausoleums can be used to distinguish between sunny and shaded slopes. Aspect is a corresponding influencing factor of "Xue". Feng-shui-suitable mausoleum areas mainly comprise sunny slopes and semi-sunny slopes.

\section{Analysis and Discussion}

\subsection{Sensitivity Analysis for the AHP-Weighted Information Content Method}

This paper analyzed the sensitivity of the AHP-weighted information method. In a sensitivity analysis, the values (336 in total) of parameters (surface roughness, elevation, surface cutting depth, surface peaks, outfall, river system, slope, and aspect) are appropriately increased or decreased in the model simulation calculations [72,73]. By comparing the simulation results, the parameters with high sensitivities among the eight influencing 
factors can be identified to determine the influence of these parameters on the suitability evaluation simulation results.

In this paper, the sensitivity of the parameters was calculated individually and consecutively using the differential method; that is, one influencing factor was changed each time, and the influence of this change in one influencing factor on the suitability evaluation results $\left(S_{i}\right.$ sensitivity) was tested. The calculation equations are shown in Equations (6) and (7).

$$
\begin{gathered}
\mathrm{R}=\mathrm{W}_{\mathrm{i}} \mathrm{I}_{\mathrm{ij}}+\mathrm{C} \\
\mathrm{S}_{\mathrm{i}}=\left(\mathrm{R}^{*}-\mathrm{R}\right) / \Delta_{\mathrm{i}}
\end{gathered}
$$

where $\mathrm{W}_{\mathrm{i}}$ is the correlation weight of influencing factors, $\mathrm{I}_{\mathrm{ij}}$ is the value of each influencing factor, and $\mathrm{C}$ represents the other unchanged influencing factors when one influencing factor is changed; here, $C$ is regarded as a constant. $R^{*}$ is the output value after the parameter change, $R$ represents the output value before the parameter change, and $\Delta_{i}$ represents the variation amplitude of parameter I.

Forty-two different assignments were made for each influencing factor, and 336 operations were carried out. Finally, the sensitivity of each influencing factor $\left(\mathrm{S}_{\mathrm{i}}\right)$ was calculated. The larger the average values were, the more sensitive the influencing factors were to the suitability evaluation results. The calculation results are shown in Figure 7. According to the calculation results, the sensitivity value of elevation was the highest, at 0.044 . The order of the other influencing factors, from large to small, was the surface cutting depth, aspect, slope, outfall, surface peaks, surface roughness and river system.

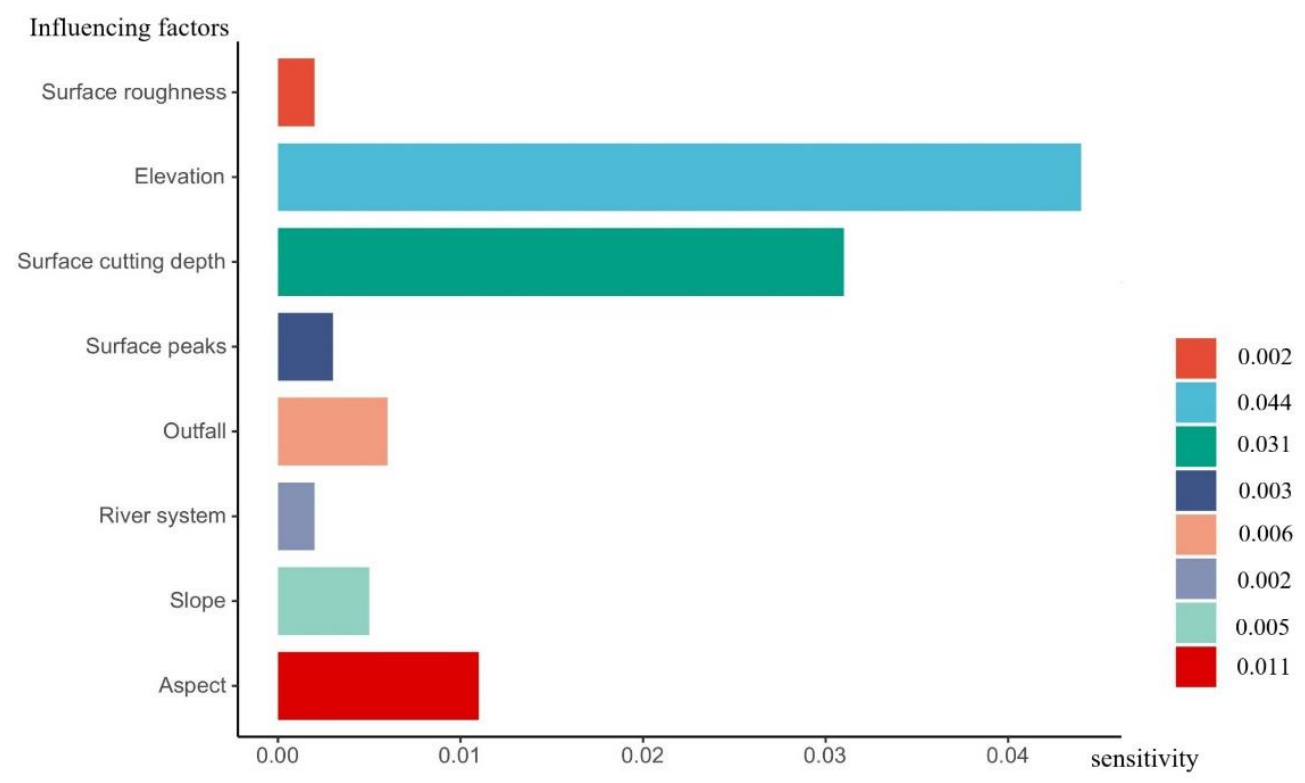

Figure 7. Sensitivity of feng shui influencing factors associated with mausoleums.

The sensitivity analysis of the AHP-I method shows that the sensitivity values of the eight influencing factors (surface roughness, elevation, surface cutting depth, surface peaks, outfall, river system, slope, and aspect) were all within the range of $0-0.5$, indicating non-sensitive parameters. This shows that in the feng shui suitability evaluation of the mausoleum model, the eight selected influencing factors were relatively appropriate, and the influence of the calculated spatial eigenvalues of the influencing factors on the feng shui suitability evaluation of the mausoleum results was within an acceptable range. Therefore, the use of the AHP-I method to evaluate the feng shui suitability of mausoleums not only avoids the subjectivity of traditional feng shui judgment methods but also scientifically explains the four feng shui elements from the perspective of mathematical statistics, more closely linking feng shui to other disciplines such as geography. In the future, we may 
combine feng shui theory with other disciplines and technologies, such as machine learning methods $[74,75]$.

\subsection{Random Mausoleums Used to Validate the Model Assessment and Analysis Results}

According to the mausoleum geomantic assessment results obtained by the AHP-I method, 26 random mausoleum sites were introduced as verification data in this paper, and the proportion of random mausoleum sites in each suitability level area was calculated. The spatial distribution of the verification data is shown in Figure 8. The 26 random mausoleum sites included 19 general minister tombs (such as the Li Ruiqing tombs, Chen Zuoqi tombs, and Tao Xingzhi tombs), 3 family cemeteries (such as the Zhao family cemetery and the Zhang Jinghou family cemetery) and 5 martyr cemeteries.

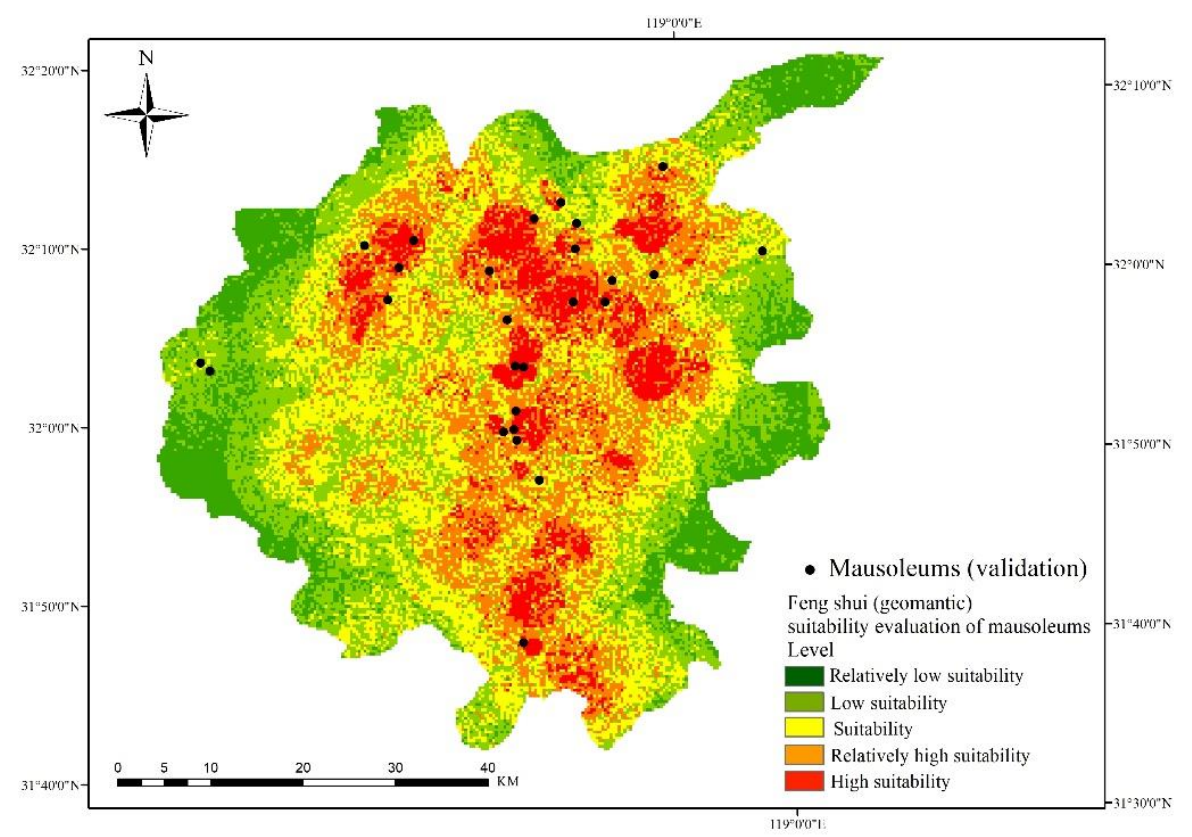

Figure 8. Validation of the geomantic assessments of 26 random tombs using the AHP-I model.

By comparing the mausoleum geomantic assessment results with the distribution of random mausoleum sites, the mausoleum geomantic assessment results were found to correspond well with the mausoleum distribution. As shown in Figure 9, of the 26 random tomb sites, 3 general minister tombs were located in relatively low-suitability and low-suitability areas, accounting for $11.54 \%$ of the overall number of sites. In contrast, five tombs were located in suitable areas, eight tombs were located in relatively high-suitability areas, and ten tombs were located in high-suitability areas, accounting for $19.23 \%, 30.77 \%$, and $38.46 \%$, respectively. Both the family cemeteries and the martyr cemeteries were located in high-suitability mausoleum geomancy areas. 


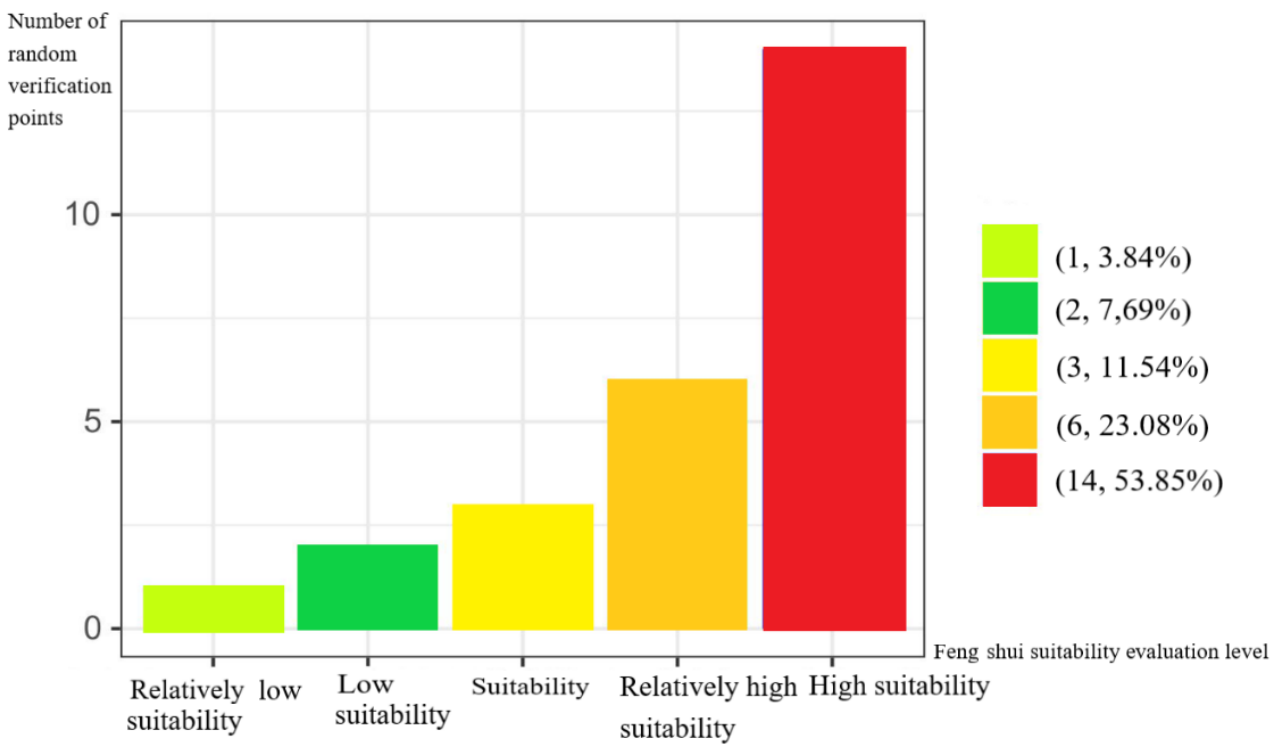

Figure 9. The proportion of random mausoleums in different geomantic assessment levels.

\subsection{Analysis of Ming Xiaoling Mausoleum Geomancy}

The Ming Xiaoling Mausoleum is the mausoleum of the emperor (Zhu Yuanzhang) and queen (Ma) of the Ming Dynasty. As the head of the Ming and Qing emperors' mausoleums in China, the Ming Xiaoling Mausoleum unified humanities and nature harmoniously and was listed as a world cultural heritage site in 2003 [76,77].

The Ming Xiaoling Mausoleum is located at Dulongfu (a large circular mound with a diameter of 325 to 400 meters and a height of approximately 70 meters) in the southern foothills of Zijin Mountain, an eastern suburb of Nanjing. Zijin Mountain has three peaks: the east, middle and west peaks. In geomancy, it is called "Huagai Three Peaks". Among the three peaks, the middle peak is the leading peak. The Ming Xiaoling Mausoleum is located within the foothills to the south of the middle peak. Looking north from Dulongfu, at the site where the Ming Xiaoling Mausoleum is located, the central mountain range of Zijin Mountain is curved; the arc mouth faces south, and the height of the mountain slowly drops towards Dulongfu. Dulongfu has an elevation above $118 \mathrm{~m}$ (in Table 7, this site belongs to rank 7), a surface roughness above 1.019 (in Table 7, it belongs to rank 1), a high terrain, and a winding mountain range. The surface cutting depth in the Ming Xiaoling Mausoleum is 17.78 (in Table 7, it belongs to rank 10), and the surrounding surface peak buffer area is 0-2 km (in Table 7, it belongs to rank 27). The superior "Long" and "Sha" of this area are important conditions that allowed it to become a geomantic treasure.

Water flows out of the mountains in the northeast direction of Dulongfu, divided into three royal rivers, respectively, from the front of the Minglou in Fangcheng, the Wenwu side door, and under the Royal River Bridge on Shixiang road; all of these rivers flow into a former lake in the southwest direction of Dulongfu. The surrounding outfall buffer area of the Ming Xiaoling Mausoleum is $0-3 \mathrm{~km}$, belonging to the first classification level (in Table 7 , this site belongs to rank 11), and its surrounding river system buffer area is $1-2 \mathrm{~km}$ (in Table 7, it belongs to rank 14). In eastern Dulongfu, Zijin Mountain extends southwards towards several hills. The slope type of Ming Xiaoling Mausoleum is between $180^{\circ}-270^{\circ}$ (in Table 7, it belongs to rank 6), and the aspect is a sunny slope (in Table 7, it belongs to rank 20). The Ming Xiaoling Mausoleum chose Dulongfu as the "Xue" and is located in an area hidden from the wind and enjoys the presence of water. The Ming Xiaoling Mausoleum has four geomantic elements ("Long", "Sha", "Shui", and "Xue") and can be called a veritable geomantic treasure, as shown in Figure 10. 


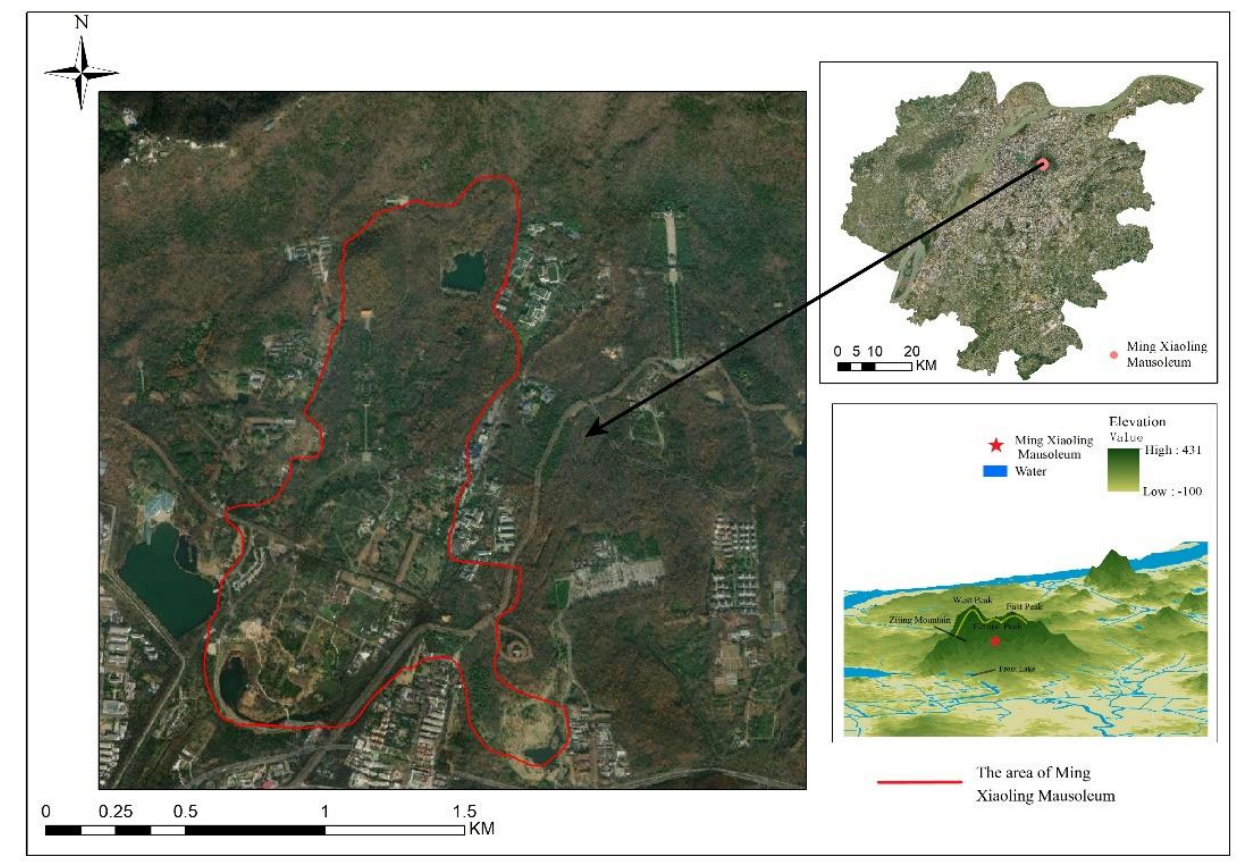

Figure 10. Geomantic diagram of Ming Xiaoling Mausoleum.

\section{Conclusions}

Based on GIS applications, this paper proposed a method that combines the correlation weighting method of each influencing factor with the classification method of individual influencing factors to assess mausoleum geomancy, which is different from the methodology of Chinese feng shui. First, the four geomantic elements of "Long, Sha, Shui, and Xue" were transformed into corresponding environmental influencing factors of mausoleums (surface roughness, elevation, surface cutting depth, surface peaks, outfall, river system, slope, and aspect). Then, the analytical hierarchy process (AHP) was used within the correlation weighting method of each influencing factor to calculate the weights of the eight influencing factors, and the information content method (I) was applied in the classification method of individual influencing factors to calculate the grading numerical index of each influencing factor. Finally, a mausoleum geomantic assessment model (AHP-I) was constructed by the comprehensive weighting method, and the mausoleum geomancy in the main urban area of Nanjing was assessed. Then, combined with the sensitivity analysis of the model, a random mausoleum site assessment analysis and a Ming Xiaoling Mausoleum geomantic assessment analysis, two methods were used to verify the assessment results of the model. The following conclusions were drawn:

(1) According to the results of the mausoleum geomantic assessment conducted in the main urban area of Nanjing, the relatively low-suitability area accounted for $14.55 \%$ of the overall studied mausoleums, the low-suitability area accounted for $25.40 \%$, the suitable area accounted for $29.13 \%$, the relatively high-suitability area accounted for $22.00 \%$, and the high-suitability area accounted for $8.92 \%$.

(2) The results of the mausoleum geomantic assessment were consistent with the actual distribution of mausoleums, and based on GIS and AHP applications, the weighted information method is applicable for evaluating the feng shui suitability of mausoleums.

Author Contributions: Conceptualization, Jing Cui and Handong He; methodology, Jing Cui and Handong $\mathrm{He}$; software, Jing Cui and Yanrong Liu; validation, Junlin Sun, and Di Hu; formal analysis, Jing Cui and Handong He; investigation, Yanrong Liu and Junlin Sun; resources, Jing Cui and Handong He; data curation, Jing Cui and Yanrong Liu; writing—original draft preparation, Jing Cui; writing—review and editing, Yanrong Liu, Junlin Sun, Di Hu, and Handong He; visualization, Jing Cui and Yanrong Liu; supervision, Di $\mathrm{Hu}$, and Handong He; project administration, Jing Cui and Handong He; funding acquisition, Di Hu, and Handong He. All authors have read and agreed to the published version of the manuscript. 
Funding: This work is supported by the National Natural Science Foundations of China (No. 42071365,41771421 ) and by the National Undergraduate Innovation and Entrepreneurship Training Program (No.201910364245).

Institutional Review Board Statement: No applicable.

Informed Consent Statement: No applicable.

Data Availability Statement: The data presented in this study are available on request from the corresponding author. The data are not publicly available due to privacy issues.

Acknowledgments: We would like to express our sincere thanks to the anonymous reviewers and editors for their valuable comments and suggestions for this paper.

Conflicts of Interest: The authors declare that they have no conflict of interest.

\section{References}

1. Jiao, N.F.; Li, G. On the Issues Related to the Eastern Mausoleum of the Qin State. Archaeol. Cult Relics 2021, 1, 94-99.

2. Liu, Z.Z. Type of Tomb Walls of the Han Dynasty and Related Issues. J. Natl. Mus. China 2020, 2, 6-19.

3. Yoon, H.-k. Ideas relating to humanity-nature relationships in Korean folk narratives reflecting geomantic values. Landsc. Res. 2021, 46, 782-792. [CrossRef]

4. Shin, J.-h. Prevalent grave geomancy during late Chosen dynasty and Chengyagyong's understanding on geomancy. Jangseogak 2015, 34, 230-255.

5. Lin, C.C.; Chen, C.L.; Twu, Y.C. An Estimation of the Impact of Feng-Shui on Housing Prices in TaiwanGA Quantile Regression Application. Int. Real Estate Rev. 2012, 15, 325-346. [CrossRef]

6. Wang, P.F.; Liu, E.L.; Tian, P.P. The location of Huaiyang ancient city and the relationship between the layout of water system and feng shui theory. China Anc. City 2017, 3, 56-62. (In Chinese)

7. Che, G.-M. The Impact of Feng Shui on Chinese Communication. China Media Res. 2007, 3, 102-109.

8. Park, S.J.; Choi, W.; Lee, D. The Geomorphological Forming Processes of Sashinsa in Pungsu. J. Cult. Hist. Geogr. 2014, $26,1-18$.

9. Selin, H. Encyclopaedia of the History of Science, Technology, and Medicine in Non-Western Cultures; Springer: Berlin, Germany, 2008; Volume 1, pp. 1-4.

10. Wang, P.C.; Zheng, G.Z.; Ge, X.X. On the Scientific Inquiry of the Geomancy Based on the Geography. J. Anhui Agric. Sci. 2016, 4 , 212-215.

11. $\mathrm{Xu}, \mathrm{Y}$. Fengshui in China: Geomantic Divination between State Orthodoxy and Popular Religion (review). China Rev. Int. 2004, 11, 35-41. [CrossRef]

12. Park, C.P.; Furukawa, N.; Yamada, M. A Study on the Spatial Composition of Folk Houses and Village in Taiwan for the Geomancy(Feng-Shui). Ournal-Archit. Inst. Korea 1996, 12, 129-139. (In Korean)

13. Oguma, M. A Field Study on Fengshui Relating to Village Location and Houses in Zhejiang Province, China. Okinawa Int. Univ. J. Cult. Soc. 1996, 1, 21-42.

14. Paton, M.J. Five Classics of Fengshui Chinese Spiritual Geography in Historical and Environmental Perspective; Brill: Leiden, The Netherlands, 2013; Volume 110, pp. 89-109.

15. OleBruun. The Culture of Fengshui in Korea: An Exploration of East Asian Geomancy (review). J. Korean Relig. 2011, 2, 107-109. [CrossRef]

16. Parkes, G. Fengshui; Springer: Dordrecht, The Netherlands, 2008; Volume 5, pp. 917-922.

17. Zang, Y.B. Geographical Geomancy and Humanistic Geomancy in the Visual Threshold of Ecological Aesthetics: Also on How to Get Rid of Geomancy Superstition. Hundred Sch. Arts 2014, 5, 64-67.

18. Sun, F.H. Speculation of Human-earth Harmony Theory Based on Yi Studies and Geomancy. Acta Geogr. Sin. 2012, 67, 266-282.

19. Mak, M.Y. Applications of Knowledge-Based Expert Systems to Feng Shui Knowledge. Lect. Notes Eng. Comput. Sci. 2010, $2180,1-7$.

20. Yu, Y.; Yang, Z.J. Scientificity and Rationality of Chinese Traditional Classical Fengshui Theory. Can. Soc. Sci. 2017, 13, 55-65.

21. Li, X.B. Cultural geographical perspective of Fengshui System in ancient China. Hum. Geogr. 2001, 16, 64-68.

22. Shi, Z.; Yu, T.; Shi, M. Investigate the layout and age of a large-scale mausoleum in Hangzhou, China using combined geophysical technologies and archaeological documents. Archaeol. Prospect. 2020, 27, 1774. [CrossRef]

23. Girard, L.F.; Toro, P.D. Integrated spatial assessment: A multicriteria approach to sustainable development of cultural and environmental heritage in San Marco dei Cavoti, Italy. Cent. Eur. J. Oper. Res. 2007, 15, 281-299. [CrossRef]

24. Cataldo, R.; Donno, A.; Nunzio, G.D.; Leucci, G.; Nuzzo, L.; Siviero, S. Integrated methods for analysis of deterioration of cultural heritage: The Crypt of "Cattedrale di Otranto". J. Cult. Herit. 2005, 6, 29-38. [CrossRef]

25. Nahuelhual, L.; Carmona, A.; Laterra, P.; Barrena, J.; Aguayo, M. A mapping approach to assess intangible cultural ecosystem services: The case of agriculture heritage in Southern Chile. Ecol. Indic. 2014, 40, 90-101. [CrossRef]

26. Rua, H.; Alvito, P. Living the past: 3D models, virtual reality and game engines as tools for supporting archaeology and the reconstruction of cultural heritage — the case-study of the Roman villa of Casal de Freiria. J. Archaeol. Sci. 2011, 38, 3296-3308. [CrossRef] 
27. Cetin, M.; Zeren, I.; Sevik, H.; Cakir, C.; Akpinar, H. A study on the determination of the natural park's sustainable tourism potential. Environ. Monit. Assess. 2018, 190, 167. [CrossRef] [PubMed]

28. Hadjimitsis, D.; Agapiou, A.; Alexakis, D.; Sarris, A. Exploring natural and anthropogenic risk for cultural heritage in Cyprus using remote sensing and GIS. Int. J. Digit. Earth 2013, 6, 115-142. [CrossRef]

29. Liu, P.L. A geographical evaluation of Fengshui (A Chinese geomancy) model. Hum. Geogr. 1996, 11, 36-39.

30. Yang, W.H. On the geographical basis of feng shui. Stud. Hist. Nat. Sci. 1992, 4, 367-375. (in Chinese).

31. Cao, X.; Gong, X.; Han, Q.; Meng, H. Application of evidence weight method in quantitative evaluation of faults and gold mineralization in kalamaili gold belt, xinjiang. J. Geomech. 2019, 25, 157-162.

32. Chen, W.; Li, H.; Hou, E.; Wang, S.; Wang, G.; Panahi, M.; Li, T.; Peng, T.; Guo, C.; Niu, C. GIS-based groundwater potential analysis using novel ensemble weights-of-evidence with logistic regression and functional tree models. Sci. Total Environ. 2018, 634, 853. [CrossRef]

33. Cao, Y.F.; Jia, H.L.; Xiong, J.N.; Cheng, W.M.; Li, K.; Pang, Q.; Yong, Z.W. Flash Flood Susceptibility Assessment Based on Geodetector, Certainty Factor, and Logistic Regression Analyses in Fujian Province, China. ISPRS Int. J. Geo-Inf. 2020, 9, 748. [CrossRef]

34. Li, H.F.; Chen, Y.M.; Deng, S.S.; Chen, M.J.; Fang, T.; Tan, H.Y. Eigenvector Spatial Filtering-Based Logistic Regression for Landslide Susceptibility Assessment. ISPRS Int. J. Geo-Inf. 2019, 8, 332. [CrossRef]

35. Zhao, Y.L.; Zhang, C.S.; Wang, Y.X.; Lin, H. Shear-related roughness classification and strength model of natural rock joint based on fuzzy comprehensive evaluation. Int. J. Rock Mech. Min. Sci. 2021, 137, 394-400. [CrossRef]

36. Tian, G.D.; Hao, N.N.; Zhou, M.C.; Pedrycz, W.; Zhang, C.Y.; Ma, F.W.; Li, Z.W. Fuzzy Grey Choquet Integral for Evaluation of Multicriteria Decision Making Problems With Interactive and Qualitative Indices. IEEE Trans. Syst. Man Cybern. Syst. 2021, 51, 1855-1868. [CrossRef]

37. Valkanou, K.; Karymbalis, E.; Papanastassiou, D.; Soldati, M.; Chalkias, C.; Gaki-Papanastassiou, K. Assessment of Neotectonic Landscape Deformation in Evia Island, Greece, Using GIS-Based Multi-Criteria Analysis. ISPRS Int. J. Geo-Inf. 2021, 10, 118. [CrossRef]

38. Nyimbili, P.H.; Erden, T. A Hybrid Approach Integrating Entropy-AHP and GIS for Suitability Assessment of Urban Emergency Facilities. ISPRS Int. J. Geo-Inf. 2020, 9, 419. [CrossRef]

39. Meerow, S.; Newell, J.P. Spatial planning for multifunctional green infrastructure: Growing resilience in Detroit. Landsc. Urban Plan. 2017, 159, 62-75. [CrossRef]

40. Liu, L.L.; Cao, J.P. GIS-based resource evaluation and prediction of W-Mo deposit in southern Anhui Province. J. Geol. 2017, 41, 245-250.

41. Hanselka, J.K.; King, B. Modeling Agricultural Potential Near the Ocampo Caves, Tamaulipas: Integrating Archaeological and Geospatial Applications. J. Ethnobiol. 2017, 37, 260-281. [CrossRef]

42. Ilia, I.; Tsangaratos, P. Applying weight of evidence method and sensitivity analysis to produce a landslide susceptibility map. Landslides 2016, 13, 379-397. [CrossRef]

43. Ma, W.; Xu, S.N.; Wang, R.S.; Zhao, Z.M.; Wen, Y.L. Geo-environmental Quality Assessment of Rare-earth Mines in Southern Jiangxi Province Using Weights-of-evidence Modeling. Acta Geosci. Sin. 2015, 1, 102-109.

44. Sun, X.H.; Chen, J.P.; Bao, Y.D.; Han, X.D.; Zhan, J.W.; Peng, W. Landslide Susceptibility Mapping Using Logistic Regression Analysis along the Jinsha River and Its Tributaries Close to Derong and Deqin County, Southwestern China. ISPRS Int. J. Geo-Inf. 2018, 7, 438. [CrossRef]

45. Su, Q.M.; Zhang, J.; Zhao, S.M.; Wang, L.; Liu, J.; Guo, J.L. Comparative Assessment of Three Nonlinear Approaches for Landslide Susceptibility Mapping in a Coal Mine Area. ISPRS Int. J. Geo-Inf. 2017, 6, 228. [CrossRef]

46. Shan, P.; Sun, W.J.E.E.S. Research on 3D urban landscape design and evaluation based on geographic information system. Environ. Earth Sci. 2021, 80, 597. [CrossRef]

47. Ge, P.P.; He, J.; Zhang, S.H.; Zhang, L.W.; She, J.F. An Integrated Framework Combining Multiple Human Activity Features for Land Use Classification. ISPRS Int. J. Geo-Inf. 2019, 8, 90. [CrossRef]

48. Chen, J.F.; Hsieh, H.N.; Do, Q.H. Evaluating teaching performance based on fuzzy AHP and comprehensive evaluation approach Appl. Soft Comput. 2015, 28, 100-108. [CrossRef]

49. Qiu, F.; Chastain, B.; Zhou, Y.; Zhang, C.; Sridharan, H. Modeling land suitability/capability using fuzzy evaluation. Geojournal 2014, 79, 167-182. [CrossRef]

50. Liu, Y.L.; Li, L. Mountainous City Featured Landscape Planning Based on GIS-AHP Analytical Method. ISPRS Int. J. Geo-Inf. 2020, 9, 211. [CrossRef]

51. Tavana, M.; Khosrojerdi, G.; Mina, H.; Rahman, A. A hybrid mathematical programming model for optimal project portfolio selection using fuzzy inference system and analytic hierarchy process. Eval. Program Plann. 2019, 77, 101703. [CrossRef] [PubMed]

52. Demir, G. GIS-based landslide susceptibility mapping for a part of the North Anatolian Fault Zone between Readiye and Koyulhisar (Turkey). Catena 2019, 183, 104211. [CrossRef]

53. Shrestha, S.; Kang, T.S.; Suwal, M.K. An Ensemble Model for Co-Seismic Landslide Susceptibility Using GIS and Random Forest Method. ISPRS Int. J. Geo-Inf. 2017, 6, 365. [CrossRef]

54. Zhou, G.; Cui, M.Y.; Li, Z.; Zhang, S.Q. Dynamic evaluation of the risk of the spring snowmelt flood in Xinjiang. Arid Zone Res. 2021, 4, 950-960. 
55. Wen, H.; Wang, D.; Wang, S.R.; Du, S.H.; Xiang, S.Y.; Ling, S.X.; Wu, X.Y. Key predisposing factors and susceptibility mapping of snow avalanche in parlung-tsangpo catchment, southeast tibetan plateau. J. Eng. Geol. 2021, 2, 404-415.

56. Deng, X.L.; Li, L.H.; Tan, Y.F. Validation of Spatial Prediction Models for Landslide Susceptibility Mapping by Considering Structural Similarity. ISPRS Int. J. Geo-Inf. 2017, 6, 103. [CrossRef]

57. Acharya, T.D.; Yang, I.T.; Lee, D.H. GIS-based Landslide Susceptibility Mapping of Bhotang, Nepal using Frequency Ratio and Statistical Index Methods. J. Korean Soc. Surv. Geod. Photogramm. Cartogr. 2017, 35, 357-364.

58. Reis, S.; Yalcin, A.; Atasoy, M.; Nisanci, R.; Bayrak, T.; Erduran, M.; Sancar, C.; Ekercin, S. Remote sensing and GIS-based landslide susceptibility mapping using frequency ratio and analytical hierarchy methods in Rize province (NE Turkey). Environ. Earth Sci. 2012, 66, 2063-2073. [CrossRef]

59. Yalcin, A.; Reis, S.; Aydinoglu, A.C.; Yomralioglu, T. A GIS-based comparative study of frequency ratio, analytical hierarchy process, bivariate statistics and logistics regression methods for landslide susceptibility mapping in Trabzon, NE Turkey. Catena 2011, 85, 274-287. [CrossRef]

60. Feng, J.M.; Yang, B.; Xie, R.L. Evaluation of Geological Disaster Hazard Zoning in Lueyang County, ShaanxiProvince. Geospat. Inf. 2021, 2, 78-82.

61. He, H.; Hu, D.; Sun, Q.; Zhu, L.; Liu, Y. A Landslide Susceptibility Assessment Method Based on GIS Technology and an AHP-Weighted Information Content Method: A Case Study of Southern Anhui, China. ISPRS Int. J. Geo-Inf. 2019, 8, 266. [CrossRef]

62. Wang, J.; Yin, K.; Xiao, L. Landslide susceptibility assessment based on gis and weighted information value: A case study of wanzhou district, three gorges reservoir. Chin. J. Rock Mech. Eng. 2017, 33, 797-808.

63. Bathrellos, G.D.; Skilodimou, H.D.; Chousianitis, K.; Youssef, A.M.; Pradhan, B. Suitability estimation for urban development using multi-hazard assessment map. Sci. Total Environ. 2017, 575, 119-134. [CrossRef]

64. Vaidya, O.S.; Kumar, S. Analytic hierarchy process: An overview of applications. Eur. J. Oper. Res. 2006, 169, 1-29. [CrossRef]

65. Che, V.B.; Kervyn, M.; Suh, C.E.; Fontijn, K.; Ernst, G.G.J.; Marmol, M.A.D. Landslide susceptibility assessment in limbe (SW Cameroon): A field calibrated seed cell and information value method. Catena 2012, 92, 83-98. [CrossRef]

66. Gao, K.; Cui, P.; Zhao, C.; Wei, F. Landslide hazard evaluation of wanzhou based on gis information value method in the three gorges reservoir. Chin. J. Rock Mech. Eng. 2006, 25, 991-996.

67. Mojaddadi, H.; Pradhan, B.; Nampak, H.; Ahmad, N.; Ghazali, A.H.B. Ensemble machine-learning-based geospatial approach for flood risk assessment using multi-sensor remote-sensing data and GIS. Geomat. Nat. Hazards Risk 2017, 8, 1080-1102. [CrossRef]

68. Althuwaynee, O.F.; Pradhan, B.; Lee, S. Application of an evidential belief function model in landslide susceptibility mapping Comput. Geosci. 2012, 44, 120-135. [CrossRef]

69. Joshi, P.N.; Maurya, D.M.; Chamyal, L.S. Morphotectonic segmentation and spatial variability of neotectonic activity along the Narmada-Son Fault, Western India: Remote sensing and GIS analysis. Geomorphology 2013, 180/181, 292-306. [CrossRef]

70. Zhang, S.; Wei, C.; Shang, H.; Shao, J.a. Coupling of Rural Road Network's Spatial Pattern and Landform Morphological Factors by Multilayer Perception Neural Network. NJAS Wagening. J. Life Sci. 2012, 10, 168-176. [CrossRef]

71. Qiheng, W. Research on Feng Shui Theory ; Tianjin University Press: TianJin, China, 2005; Voluem 10, pp. 169-174. (In Chinese)

72. Muhammad, U.; Thomas, R.; Rudolf, L.; Azhar, A.; Christopher, C.; Shoaib, S. Inverse Parametrization of a Regional Groundwater Flow Model with the Aid of Modelling and GIS: Test and Application of Different Approaches. Int. J. Geo-Inf. 2018, 7, 22.

73. Caporossi, P.; Mazzanti, P.; Bozzano, F. Digital Image Correlation (DIC) Analysis of the 3 December 2013 Montescaglioso Landslide (Basilicata, Southern Italy): Results from a Multi-Dataset Investigation. ISPRS Int. J. Geo-Inf. 2018, 7, 372. [CrossRef]

74. Mf, A.; Mk, A.; Mp, B.; At, A.; Adb, C.; Sja, C. Machine Learning for Cultural Heritage: A Survey-ScienceDirect. Pattern Recognit. Lett. 2020, 133, 102-108.

75. Fm, A.; Jm, B.; Tr, A.; Nnc, D.; Jwa, E.; Jog, F.; Ye, G.; Lg, H.; Aca, I.; Cs, J. Machine learning for rapid mapping of archaeological structures made of dry stones-Example of burial monuments from the Khirgisuur culture, Mongolia-ScienceDirect. J. Cult. Herit. 2020, 43, 118-128.

76. Zheng, Y.C. Reasons for Emperor Kangxi and Qianlong's Visit to Ming Xiaoling Tomb. J. China Univ. Pet. 2008, $24,82-85$.

77. David. Imperial Xiaoling Mausoleum in Nanjing. Cult Dialogue 2003, 5, 12. 